\title{
Sterically congested, geminal aryl-substituted, proton-ionizable sym-dibenzo-16-crown-5 lariat ethers: synthesis and alkali metal cation extraction
}

\section{Chuqiao Tu,* Youngchan Jang, Carrie L. Bates, Jerzy Gega, Kazimierz Surowiec, and Richard A. Bartsch}

Department of Chemistry and Biochemistry, Texas Tech University, Lubbock, Texas, 79409-1061 USA

E-mail: chqtu@ucdavis.edu

\begin{abstract}
Three series of proton-ionizable sym-dibenzo-16-crown-5 ethers with sterically demanding 1naphthyl, 2-naphthyl, and 9-phenanthryl geminal groups are synthesized and characterized. Variation of the proton-ionizable group includes oxyacetic acid and $N$-(X)sulfonyl oxyacetamide units with $\mathrm{X}=\mathrm{Me}, \mathrm{Ph}, \mathrm{C}_{6} \mathrm{H}_{4}-4-\mathrm{NO}_{2}$, and $\mathrm{CF}_{3}$. For the latter series, variation of $\mathrm{X}$ provides 'tunable' acidity of the ligand. The metal ion-complexing properties of the proton-ionizable sym(aryl)dibenzo-16-crown-5 compounds are probed by competitive solvent extraction of alkali metal cations from aqueous solutions into chloroform.
\end{abstract}

Keywords: Lariat ether, solvent extraction, alkali metal cations, crown ether

\section{Introduction}

Crown ethers, macrocyclic polyethers with a hydrophobic ring of ethylenic units surrounding a hydrophilic cavity of ether oxygen atoms, are exceptionally versatile and powerful in selectively binding a range of metal ion species. ${ }^{1-2}$ Attachment of one or more side arms onto a crown ether ring produces a lariat ether. ${ }^{3}$ This may enhance metal ion binding strength and selectivity over monocyclic crown ethers by providing donor sites in addition to those of the macroring resulting in three-dimensional complexation, thereby mimicking the dynamic complexation processes exhibited by natural macrocyclic ionophores. ${ }^{3}$ However, such complexing agents may not be effective in practical extractions of metal ions due to the low distribution coefficients of common counteranions, such as chloride, nitrate, and sulfate between an aqueous phase and a contacting organic phase. ${ }^{4}$ This problem can be overcome by attaching a proton-ionizable side arm to the crown ether ring so that the ligand provides not only a polyether binding site for metal ion complexation, but also the requisite anion for formation of an electroneutral extraction complex. 
An ionizable group on the side arm eliminates the need to transfer one or more aqueous phase anions into the organic phase by operating in a cation-exchange mode with the metal ion. Following the extraction step, shaking of the separated organic phase with aqueous acid strips the extracted metal ions into a new aqueous phase and regenerates the neutral form of the extractant. $^{4-5}$

During a metal ion separation process, the presence of lipophilic groups on the crown ether ring is important in reducing loss of the macrocyclic ligand from an organic phase into a contacting aqueous phase. ${ }^{6}$ The dibenzo-16-crown-5 ring system provides a convenient scaffold for investigating the influence of structural variation within lariat ethers upon their selectivity and efficiency in metal ion complexation processes due to its synthetic accessibility with pendant groups attached to the central carbon of the three-carbon bridge. ${ }^{7-8}$ In earlier studies, we found that the introduction of a lipophilic decyl group geminal to the functional side arm in symdibenzo-16-crown-5 oxyacetic acid (Figure 1) increased the $\mathrm{Na}^{+}$selectivity by preorganization of the binding site in which the alkyl group oriented the oxyacetic acid side arm over the polyether cavity. ${ }^{9}$
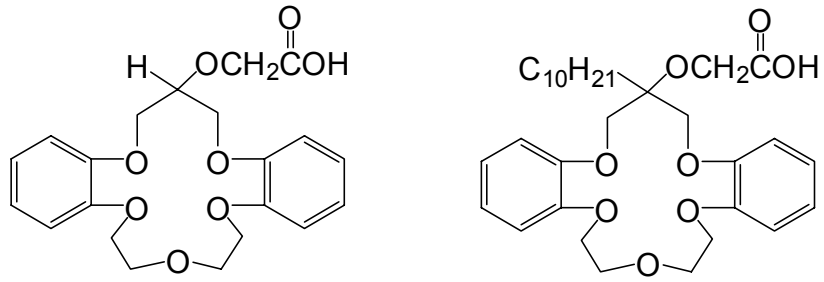

Figure 1. Structures of sym-dibenzo-16-crown-5-oxyacetic acid and sym-(decyl)dibenzo-16crown-5-oxyacetic acid.

Various alkyl groups have been attached geminal to the proton-ionizable side arm in symdibenzo-16-crown-5 ethers to form effective and selective extractants for alkali metal cations. ${ }^{5-6}$ In comparison, analogues with more sterically demanding geminal aryl groups have received very little attention. We now report the synthesis of three series of proton-ionizable sym-dibenzo16-crown-5 ethers with geminal 1-naphthyl, 2-naphthyl, and 9-phenanthryl groups (Figure 2).

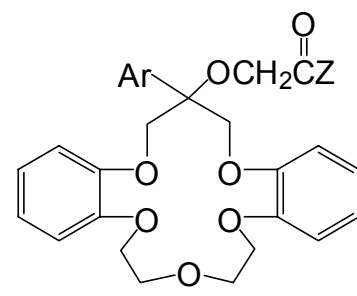

Ar = 1-naphthyl, 2-naphthyl, 9-phenanthryl

$\mathrm{Z}=\mathrm{OH}, \mathrm{NHSO}_{2} \mathrm{Me}, \mathrm{NHSO}_{2} \mathrm{Ph}, \mathrm{NHSO}_{2} \mathrm{C}_{6} \mathrm{H}_{4}-4-\mathrm{NO}_{2}, \mathrm{NHSO}_{2} \mathrm{CF}_{3}$

Figure 2. Structures of new proton-ionizable sym-(aryl)dibenzo-16-crown-5 ethers.

Variation of the proton-ionizable side arms include oxyacetic acid moieties and $\mathrm{N}$ (X)sulfonyl oxyacetamide units with $\mathrm{X}=\mathrm{Me}, \mathrm{Ph}, \mathrm{C}_{6} \mathrm{H}_{4}-4-\mathrm{NO}_{2}$, and $\mathrm{CF}_{3} .{ }^{10}$ For the latter series, 
variation of the electron-withdrawing properties of X 'tunes' the acidity of the functional side arm. The influence of sterically hindered geminal aryl groups on metal ion complexation is evaluated in competitive solvent extraction of alkali metal cations from aqueous solutions into chloroform.

\section{Results and Discussion}

\section{Synthetic routes}

The synthetic routes to the new proton-ionizable sym-(1-naphthyl)- and sym-(2naphthyl)dibenzo-16-crown-5 ethers are shown in Scheme 1.<smiles>OCCOCCOc1ccccc1OCCOc1ccccc1OCCO</smiles>

1<smiles>O=C(COc1ccccc1)COc1ccccc1OCCOCCO</smiles>

2<smiles>CCC(O)(COc1ccccc1OCCOCCOc1ccccc1)C(F)(F)F</smiles>

Ar

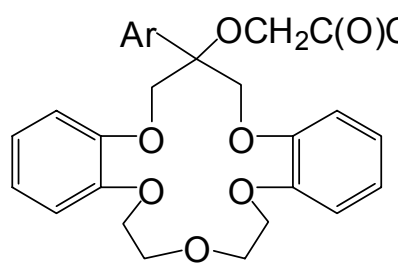

$\mathrm{Ar}$

8 1-naphthyl

9 2-naphthyl

$g$<smiles>CC(C)C(CO)(COc1ccccc1OCCOCCOc1ccccc1)OCC=O</smiles>

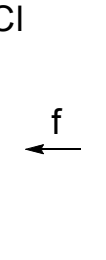

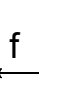

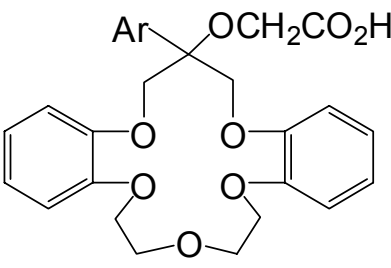

Ar

6 1-naphthyl

7 2-naphthyl
4 2-naphthyl

$d \downarrow$

$$
\text { c/ }
$$

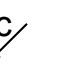<smiles>COc1ccccc1OCCOCCOc1ccccc1OCC(OCC(C)=O)(C(C)(F)F)C(F)(F)F</smiles>

Ar

5 1-naphthyl

\begin{tabular}{lll} 
& \multicolumn{1}{|c}{} & $\underline{\mathrm{X}}$ \\
10 & 1-naphthyl & $\mathrm{Me}$ \\
11 & 1-naphthyl & $\mathrm{Ph}$ \\
12 & 1-naphthyl & $\mathrm{C}_{6} \mathrm{H}_{4}-4-\mathrm{NO}_{2}$ \\
13 & 1-naphthyl & $\mathrm{CF}_{3}$ \\
14 & 2-naphthyl & $\mathrm{Me}$ \\
15 & 2-naphthyl & $\mathrm{Ph}$ \\
16 & 2-naphthyl & $\mathrm{C}_{6} \mathrm{H}_{4}-4-\mathrm{NO}_{2}$ \\
17 & 2-naphthyl & $\mathrm{CF}_{3}$
\end{tabular}

Scheme 1. Synthesis of proton-ionizable sym-(1-naphthyl)dibenzo-16-crown-5 ethers 6 and 1013 and sym-(2-naphthyl)dibenzo-16-crown-5 ethers 7 and 14-17. Reagents and conditions: (a) $(\mathrm{COCl})_{2}, \mathrm{DMSO}, \mathrm{Et}_{3} \mathrm{~N}, \mathrm{CH}_{2} \mathrm{Cl}_{2},-78^{\circ} \rightarrow 0^{\circ} \mathrm{C}$; b) i) $\mathrm{ArBr}, \mathrm{Mg}$, THF; ii) $5 \% \mathrm{NH}_{4} \mathrm{Cl}(\mathrm{aq})$; c) $\mathrm{NaH}$, $\mathrm{BrCH}_{2} \mathrm{CO}_{2} \mathrm{H}$, THF, rt; d) $\mathrm{NaH}, \mathrm{BrCH}_{2} \mathrm{CO}_{2} \mathrm{Me}$, THF, rt; e) i) $10 \%$ aq. $\mathrm{NaOH}, \mathrm{THF}$, rt; ii) $6 \mathrm{~N}$ $\left.\mathrm{HCl}(\mathrm{aq}) ; \mathrm{f})(\mathrm{COCl})_{2}, \mathrm{C}_{6} \mathrm{H}_{6}, \mathrm{rt} ; \mathrm{g}\right) \mathrm{NaH}, \mathrm{NH}_{2} \mathrm{SO}_{2} \mathrm{X}, \mathrm{THF}$, rt. 
Preparation of sym-(keto)dibenzo-16-crown-5 (2) was accomplished in improved yield by the Swern oxidation of sym-(hydroxy)dibenzo-16-crown-5 (1). The lariat ether alcohols 3 and 4 were synthesized by the addition of 1-naphthyl- and 2-naphthylmagnesium bromides, respectively, to ketone 2 . The Grignard reagents were formed by addition of a solution of the aryl bromide in THF to dry magnesium turnings. The mixture was heated to initiate the reaction, then stirred at room temperature until a colored solution was observed. Tertiary alcohols $\mathbf{3}$ and $\mathbf{4}$ were obtained in 95 and $90 \%$ yields, respectively.

Deprotonation of alcohol 4 with $\mathrm{NaH}$ in THF followed by addition of dry bromoacetic acid gave sym-(2-naphthyl)dibenzo-16-crown-5-oxyacetic acid 7 in 82\% yield. However, analogous reaction of alcohol 3 gave only a low yield of lariat ether carboxylic acid $\mathbf{6}$. In an alternate route, a solution of methyl bromoacetate in THF was added to the deprotonated alcohol $\mathbf{3}$ in THF to produce methyl sym-(1-naphthyl)dibenzo-16-crown-5-oxyacetate (5) in 79\% yield. Subsequent stirring of the ester with aqueous $10 \% \mathrm{NaOH}$ and THF followed by protonation of the resultant lariat ether carboxylate gave 6 in $85 \%$ yield.

Synthesis of $N$-(X)sulfonyl sym-(aryl)dibenzo-16-crown-5-oxyacetamides 10-17 from the corresponding carboxylic acids 6 and 7 was accomplished by a two-step procedure. First, the carboxylic acid was reacted with oxalyl chloride in benzene to give the corresponding acid chloride. Formation of the acid chloride was verified by IR spectroscopy with the appearance of the strong carbonyl group absorption near $1810 \mathrm{~cm}^{-1}$ and the disappearance of the carbonyl group absorption around $1730 \mathrm{~cm}^{-1}$. ${ }^{11-12}$ The crude acid chloride was reacted with the corresponding sodium sulfonamide anions in THF to afford proton-ionizable sym-(aryl)dibenzo-16-crown-5 ethers $\mathbf{1 0 - 1 7}$ in $37-75 \%$ yields.

The synthetic route to the new proton-ionizable sym-(9-phenanthryl)dibenzo-16-crown-5 ethers is presented in Scheme 2. To initiate formation of the Grignard reagent from 9phenanthryl bromide and $\mathrm{Mg}$ in THF, a crystal of iodine was needed. A solution of ketone $\mathbf{2}$ in THF was added to the Grignard reagent and the mixture was stirred overnight. After workup, lariat ether tertiary alcohol 18 was obtained in $82 \%$ yield. Attempted reaction of alcohol 18 with $\mathrm{NaH}$ and bromoacetic acid in THF was unsuccessful. In an alternative synthetic route, the alcohol precursor was deprotonated by $\mathrm{NaH}$ in THF and ethyl bromoacetate was added. After reaction and workup, the product was found to be the lariat ether carboxylate 19 instead of the anticipated ethyl ester. This was unusual since similar reactions reported in literature always gave esters. ${ }^{13-14}$ Protonation of the lariat ether carboxylate gave the target lariat ether carboxylic acid 19 in 91\% yield. As described earlier, the carboxylic acid 19 was converted into the corresponding acid chloride $\mathbf{2 0}$ by reaction with oxalyl chloride in benzene followed by reaction of the crude acid chloride with the appropriate sodium sulfonamide in THF to produce the proton-ionizable sym-(9-phenanthryl)dibenzo-16-crown-5 ethers 21-24 in 70-94\% yields.

The new proton-ionizable sym-(aryl)dibenzo-16-crown-5 lariat ethers 6, 7, 10-17, 19, and 21-24 were characterized by IR spectrophotometry, ${ }^{1} \mathrm{H}$ and ${ }^{13} \mathrm{C}$ NMR spectroscopy, and combustion analysis. 
<smiles>O=C(COc1ccccc1)COc1ccccc1OCCOCCO</smiles>

2<smiles>CC(O)(COc1ccccc1OCCOCCOc1ccccc1)C1(C)CCCCC1</smiles>

18<smiles>O=C(O)COC(Br)(COc1ccccc1)COc1ccccc1OCCOCCO</smiles>

19<smiles>O=C(Cl)COC(CBr)(CBr)COc1ccccc1OCCOCCOc1ccccc1OCC(Cl)(Br)Br</smiles>

20

Scheme 2. Synthesis of proton-ionizable sym-(9-phenanthryl)dibenzo-16-crown-5 ethers 19 and 21-24. Reagents and conditions: a) i) 9-phenanthryl bromide, $\mathrm{Mg}, \mathrm{I}_{2}$ (cat), THF; ii) 5\% $\mathrm{NH}_{4} \mathrm{Cl}$ (aq); b) $\mathrm{NaH}, \mathrm{BrCH}_{2} \mathrm{CO}_{2} \mathrm{Et}$, THF, rt; c) $(\mathrm{COCl})_{2}, \mathrm{C}_{6} \mathrm{H}_{6}, \mathrm{rt}$; d) $\mathrm{NaH}, \mathrm{NH}_{2} \mathrm{SO}_{2} \mathrm{X}, \mathrm{THF}$, rt.

For each of the three series of compounds with $\mathrm{N}$-(X)sulfonyl oxyacetamide functional side arms, the carbonyl group IR absorption increased in wavenumbers as the electron-withdrawing ability of $\mathrm{X}$ was enhanced in the order $\mathrm{Me} \leq \mathrm{Ph}<\mathrm{C}_{6} \mathrm{H}_{4}-4-\mathrm{NO}_{2}<\mathrm{CF}_{3}$ (Table 1).

Table 1. Carbonyl stretching absorptions in wavenumbers for $N$-(X)sulfonyl oxyacetamide lariat ethers 10-17 and 21-24

\begin{tabular}{lccc}
\hline & \multicolumn{3}{c}{ Geminal Group } \\
\cline { 2 - 4 } $\mathrm{X}$ & 1719 & 2-Naphthyl & 9-Phenanthryl \\
\hline $\mathrm{Me}$ & 1726 & 1723 & 1722 \\
$\mathrm{Ph}$ & 1731 & 1723 & 1723 \\
$\mathrm{C}_{6} \mathrm{H}_{4}-4-\mathrm{NO}_{2}$ & 1758 & 1729 & 1728 \\
$\mathrm{CF}_{3}$ & & 1754 & 1748 \\
\hline
\end{tabular}

Also in the ${ }^{1} \mathrm{H}$ NMR spectra for $N$-(X)sulfonyl oxyacetamides 10-17 and 21-24, the NH peaks for each of the three series shifted further downfield as the electron-withdrawing ability of $\mathrm{X}$ increased in the order $\mathrm{Me}<\mathrm{Ph}<\mathrm{C}_{6} \mathrm{H}_{4}-4-\mathrm{NO}_{2}<\mathrm{CF}_{3}$ (Table 2). 
Table 2. Chemical shifts in $\mathrm{CDCl}_{3}$ for $\mathrm{NH}$ in ppm for $\mathrm{N}-(\mathrm{X})$ sulfonyl oxyacetamide lariat ethers 10-17 and 21-24

\begin{tabular}{lccc}
\hline & \multicolumn{3}{c}{ Geminal Group } \\
\cline { 2 - 4 } $\mathrm{X}$ & 1-Naphthyl & 2-Naphthyl & 9-Phenanthryl \\
\hline $\mathrm{Me}$ & 9.52 & 9.57 & 9.58 \\
$\mathrm{Ph}$ & 9.67 & 9.72 & 9.72 \\
$\mathrm{C}_{6} \mathrm{H}_{4}-4-\mathrm{NO}_{2}$ & 9.81 & 9.80 & 9.85 \\
$\mathrm{CF}_{3}$ & 10.13 & 10.14 & 10.16 \\
\hline
\end{tabular}

${ }^{1} \mathrm{H}$ NMR spectroscopy provides qualitative information about the flexibility of the crown ether ring. ${ }^{5,9}$ Lariat ethers with a three-carbon bridge have two limiting conformations in solution, as illustrated in Figure 3. The two methylene protons in the three-carbon bridge are diastereotopic. The rate of conformational inversion can be estimated from the spin pattern of the geminal protons. An $\mathrm{AB}$ pattern results from rapid conformational inversion, which indicates a flexible ring structure. Interesting differences are observed in the ${ }^{1} \mathrm{H}$ NMR spectra of the $\mathrm{N}$ (X)sulfonyl sym-(aryl)dibenzo-16-crown-5-oxyacetamides 10-17 and 21-24 in $\mathrm{CDCl}_{3}$. $\mathrm{AB}$ patterns were found when the aryl group was 1-naphthyl and 9-phenanthryl; whereas AX patterns were noted when the aryl group was 2-naphthyl. By this measure, the crown ether rings in the proton-ionizable sym-(2-naphthyl)dibenzo-16-crown-5 lariat ethers 6 and 10-13 in solution are judged be more rigid. Of the lariat ether carboxylic acids, 7 with a 2-naphthyl group was insoluble in $\mathrm{CDCl}_{3}$. In $\mathrm{d}_{6}$-DMSO, an $\mathrm{AB}$ pattern was observed. In $\mathrm{CDCl}_{3}, 6$ with a 1-naphthyl group exhibited an $A B$ pattern and $\mathbf{1 9}$ with a 9-phenanthryl group showed an $\mathrm{A}_{2}$ singlet for the geminal protons on the three-carbon bridge.

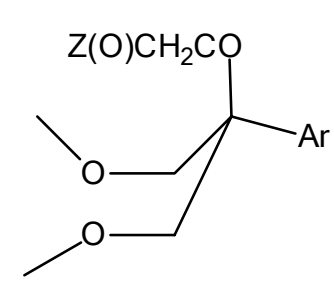

pseudo-axial

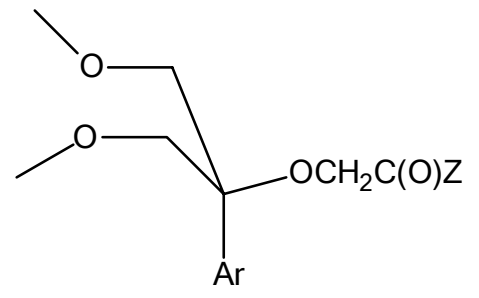

pseudo-equatorial

Figure 3. Limiting conformations of a geminally substituted lariat ether with a three-carbon bridge. 


\section{Competitive solvent extraction of alkali metal ions}

The metal ion-complexing properties of proton-ionizable lariat ethers 6, 7, 10-17, 19, and 21-24 were evaluated by competitive solvent extraction of alkali metal cations from aqueous solutions into chloroform. Aqueous solutions of $\mathrm{Li}^{+}, \mathrm{Na}^{+}, \mathrm{K}^{+}, \mathrm{Rb}^{+}$, and $\mathrm{Cs}^{+}(10 \mathrm{mM}$ in each) with varying $\mathrm{pH}$ were extracted with equal volumes of chloroform containing $1.0 \mathrm{mM}$ proton-ionizable lariat ether. After separation of the chloroform layer, it was stripped with $0.1 \mathrm{M}$ aqueous $\mathrm{HCl}$. Alkali metal cation concentrations in the strippants were determined by ion chromatography.

Extraction results for the three sym-(aryl)dibenzo-16-crown-5-oxyacetic acids 6, 7, and 19 with geminal 1-naphthyl, 2-naphthyl, and 9-phenanthryl groups, respectively, are presented in Figure 4. As is readily evident, all three ligands are highly selective extractants for $\mathrm{Na}^{+}$. The extraction selectivity order is $\mathrm{Na}^{+}>\mathrm{K}^{+}>\mathrm{Li}^{+}, \mathrm{Rb}^{+}, \mathrm{Cs}^{+}$with barely detectable or negligible levels of the last three alkali metal cations. The maximal $\mathrm{Na}^{+} / \mathrm{K}^{+}$selectivities for $\mathbf{6}$, 7, and $\mathbf{1 9}$ exceeded 100, which is the precision of the alkali metal cation analysis. In comparison, a $\mathrm{Na}^{+} / \mathrm{K}^{+}$ ratio of 27 was reported for competitive alkali metal cation extraction by sym-(decyl)dibenzo-16crown-5-oxyacetic acid. ${ }^{6}$ Thus replacement of the geminal linear alkyl group in the lariat ether carboxylic acids with geminal 1-naphthyl, 2-naphthyl, and 9-phenanthryl units produces a marked enhancement in the selectivity for $\mathrm{Na}^{+}$extraction. Alkali metal cation loading is nearly quantitative for formation of 1:1 ionized lariat ether-metal ion extraction complexes. Such high extraction selectivity for $\mathrm{Na}^{+}$strongly suggests simultaneous metal ion complexation by the polyether oxygens and the oxyacetic acid side arm. ${ }^{6,9}$

A qualitative measure of acidity for proton-ionizable ligands is $\mathrm{pH}_{0.5}$, the aqueous phase $\mathrm{pH}$ at which half of the maximal metal ion loading is reached. ${ }^{15}$ For lariat ether carboxylic acids 6,7 , and 19, the same $\mathrm{pH}_{0.5}$ value of 7.0 was observed. Thus structural variation of the geminal aryl group from 1-naphthyl to 2-naphthyl to 9-phenanthryl in the sym-(aryl)dibenzo-16-crown-5oxyacetic acid extractants did not influence the ligand acidity.

Extraction results for the $N$-(X)sulfonyl sym-(1-naphthyl)dibenzo-16-crown-5oxyacetamides 10-13 with $\mathrm{X}=\mathrm{Me}, \mathrm{Ph}, \mathrm{C}_{6} \mathrm{H}_{4}-4-\mathrm{NO}_{2}$, and $\mathrm{CF}_{3}$, respectively, are shown in Figure 5. Although the extraction selectivity order is once again $\mathrm{Na}^{+}>>\mathrm{K}^{+}>\mathrm{Li}^{+}, \mathrm{Rb}^{+}, \mathrm{Cs}^{+}$, the maximum $\mathrm{Na}^{+} / \mathrm{K}^{+}$selectivities in the range of $26-54$ are well below the $>100$ value observed with the carboxylic acid analog 6 . The $\mathrm{Na}^{+} / \mathrm{K}^{+}$ratios are similar to those of $47-49$ reported earlier ${ }^{10}$ for alkali metal cation extractions by $N$-(X)sulfonyl sym-(decyl)dibenzo-16-crown-5oxyacetamides. The $\mathrm{pH}_{0.5}$ values for 10-13 are 7.4, 7.4, 6.4, and 3.0, respectively. This ordering is consistent with enhanced acidity as the electron-withdrawing propensity of $\mathrm{X}$ is increased. 


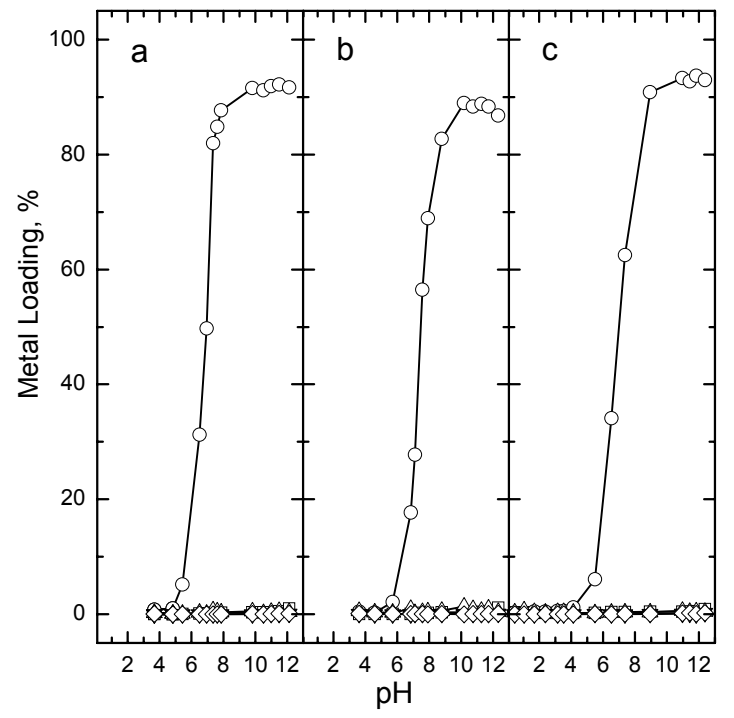

Figure 4. Percent metal loading $v s$. the equilibrium $\mathrm{pH}$ of the aqueous phase for competitive solvent extraction of alkali metal ions into chloroform by sym-(aryl)dibenzo-16-crown-5oxyacetic acids a) 6 with aryl $=1$-naphthyl, b) 7 with aryl $=2$-naphthyl, and c) 19 with aryl $=9$ phenanthryl. $\left(\square=\mathrm{Li}^{+} ; \circ=\mathrm{Na}^{+} ; \Delta=\mathrm{K}^{+} ; \boldsymbol{\nabla}=\mathrm{Rb}^{+}, \diamond=\mathrm{Cs}^{+}\right)$.

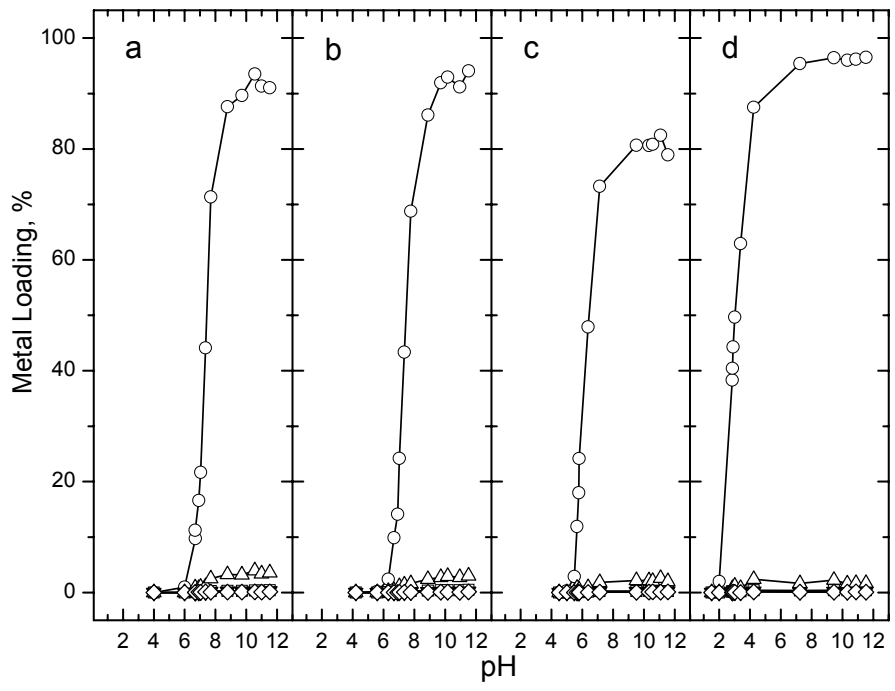

Figure 5. Percent metal loading $v s$. equilibrium $\mathrm{pH}$ of the aqueous phase for competitive solvent extraction of alkali metal ions into chloroform by $N$-(X)sulfonyl sym-(1-naphthyl)dibenzo-16crown-5-oxyacetamides a) 10 with $\mathrm{X}=\mathrm{Me}$, b) 11 with $\mathrm{X}=\mathrm{Ph}$, c) 12 with $\mathrm{X}=\mathrm{C}_{6} \mathrm{H}_{4}-4-\mathrm{NO}_{2}$, and d) 13 with $\mathrm{X}=\mathrm{CF}_{3}$. $\left(\square=\mathrm{Li}^{+} ; \circ=\mathrm{Na}^{+} ; \Delta=\mathrm{K}^{+} ; \boldsymbol{\nabla}=\mathrm{Rb}^{+}, \diamond=\mathrm{Cs}^{+}\right)$. 
Extraction results for the $N$-(X)sulfonyl sym-(2-naphthyl)dibenzo-16-crown-5oxyacetamides 14-17 with $\mathrm{X}=\mathrm{Me}, \mathrm{Ph}, \mathrm{C}_{6} \mathrm{H}_{4}-4-\mathrm{NO}_{2}$, and $\mathrm{CF}_{3}$, respectively, are shown in Figure 6. The extraction selectivity order is once again $\mathrm{Na}^{+}>>\mathrm{K}^{+}>\mathrm{Li}^{+}, \mathrm{Rb}^{+}, \mathrm{Cs}^{+}$, but with maximum $\mathrm{Na}^{+} / \mathrm{K}^{+}$selectivities of 17-35 which are far below the $>100$ value observed with the carboxylic acid analog 7. It should be noted that for a given $\mathrm{X}$ group the maximum $\mathrm{Na}^{+} / \mathrm{K}^{+}$selectivity for a member of the $\mathrm{N}$-(X)sulfonyl sym-(2-naphthyl)dibenzo-16-crown-5-oxyacetamide series was consistently less than that found for the $N$-(X)sulfonyl sym-(1-naphthyl)dibenzo-16-crown-5oxyacetamide series. The $\mathrm{pH}_{0.5}$ values for 14-17 are 7.9, 8.0, 6.8, and 3.8, respectively, which is consistent with the electron-withdrawing power of $\mathrm{X}$.

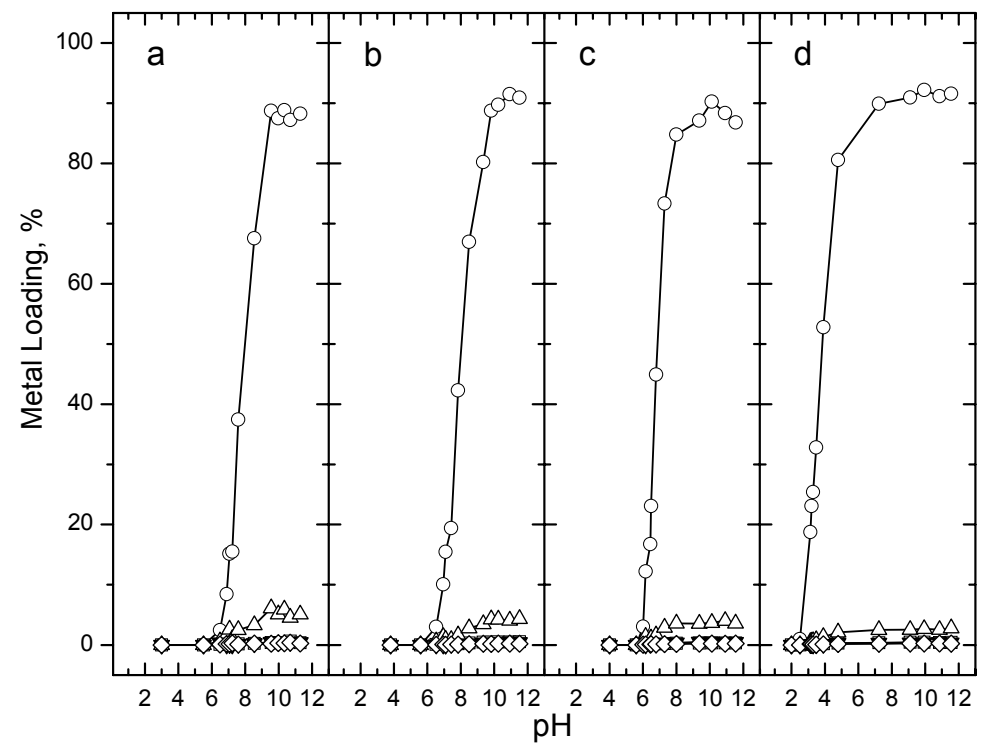

Figure 6. Percent metal loading $v s$. equilibrium $\mathrm{pH}$ of the aqueous phase for competitive solvent extraction of alkali metal ions into chloroform by $N-(\mathrm{X})$ sulfonyl sym-(2-naphthyl)dibenzo-16crown-5-oxyacetamides (a) 14 with $\mathrm{X}=\mathrm{Me}$, (b) 15 with $\mathrm{X}=\mathrm{Ph}$, (c) 16 with $\mathrm{X}=\mathrm{C}_{6} \mathrm{H}_{4}-4-\mathrm{NO}_{2}$, and (d) 17 with $\mathrm{X}=\mathrm{CF}_{3}$. $\left(\square=\mathrm{Li}^{+} ; \circ=\mathrm{Na}^{+} ; \Delta=\mathrm{K}^{+} ; \nabla=\mathrm{Rb}^{+}, \diamond=\mathrm{Cs}^{+}\right)$.

Alkali metal cation extraction profiles for the $N$-(X)sulfonyl sym-(9-phenanthryl)-dibenzo16-crown-5-oxyacetamides 21-24 with $\mathrm{X}=\mathrm{Me}, \mathrm{Ph}, \mathrm{C}_{6} \mathrm{H}_{4}-4-\mathrm{NO}_{2}$, and $\mathrm{CF}_{3}$, respectively, are presented in Figure 7. The extraction selectivity order is $\mathrm{Na}^{+}>>\mathrm{K}^{+}>\mathrm{Li}^{+}, \mathrm{Rb}^{+}, \mathrm{Cs}^{+}$. $\mathrm{The} \mathrm{Na}^{+}$ extraction selectivities more closely resemble those for $N$-(X)sulfonyl sym-(1-naphthyl)dibenzo16-crown-5-oxyacetamide analogues than for the analogous $N$-(X)sulfonyl sym-(2naphthyl)dibenzo-16-crown-5-oxyacetamide compounds. The $\mathrm{pH}_{0.5}$ values for extractants 21-24 are 7.7, 7.5, 6.3, and 3.0, respectively, in agreement with the electron-withdrawing ability of X. 
Magnitudes of the $\mathrm{pH}_{0.5}$ values for a given $\mathrm{X}$ when the geminal group is 9-phenanthryl are more similar to those when the geminal group is 1-naphthyl than 2-naphthyl.

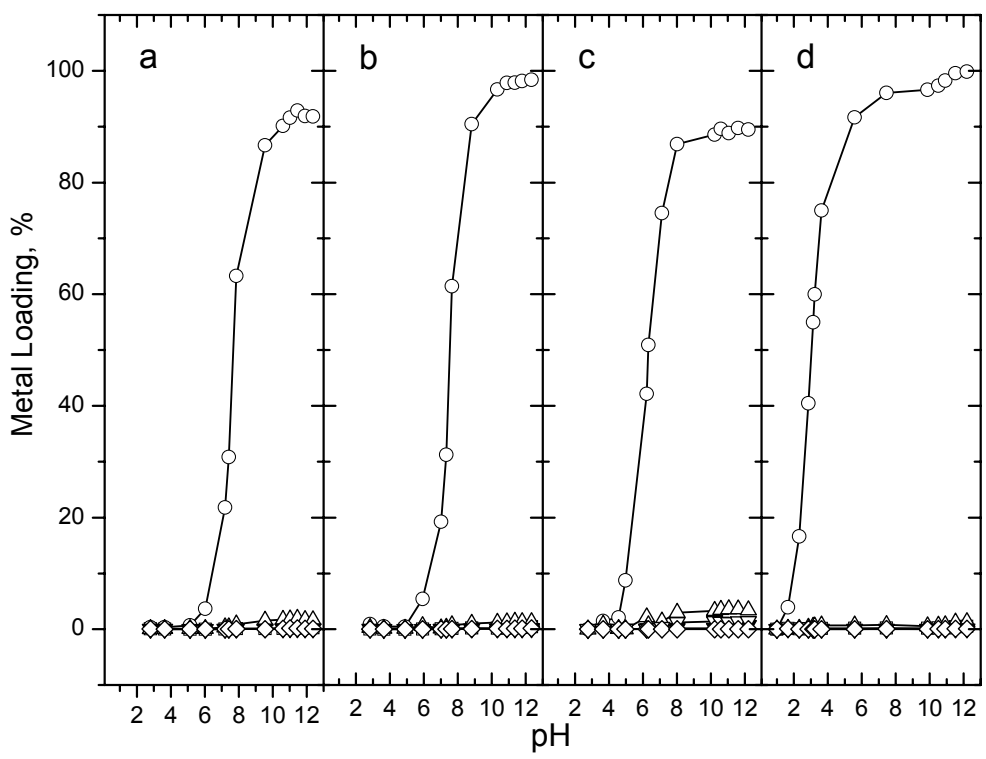

Figure 7. Percent metal loading $v s$. equilibrium $\mathrm{pH}$ of the aqueous phase for competitive solvent extraction of alkali metal ions into chloroform by $N$-(X)sulfonyl sym-(2-naphthyl)dibenzo-16crown-5-oxyacetamides (a) 21 with $\mathrm{X}=\mathrm{Me}$, (b) 22 with $\mathrm{X}=\mathrm{Ph}$, (c) 23 with $\mathrm{X}=\mathrm{C}_{6} \mathrm{H}_{4}-4-\mathrm{NO}_{2}$, and d) 24 with $\mathrm{X}=\mathrm{CF}_{3}$. $\left(\square=\mathrm{Li}^{+} ; \circ=\mathrm{Na}^{+} ; \Delta=\mathrm{K}^{+} ; \boldsymbol{\nabla}=\mathrm{Rb}^{+}, \diamond=\mathrm{Cs}^{+}\right)$.

\section{Conclusions}

Three series of proton-ionizable sym-(aryl)dibenzo-16-crown-5 ligands with systematic structural variations in the geminal aryl group and the functional side arm have been synthesized. The aryl group identity was varied to include 1-naphthyl, 2-naphthyl, and 9-phenanthryl. Functional side arms employed were oxyacetic acid and $N-(\mathrm{X})$ sulfonyl oxyacetamide with changes of $\mathrm{X}$ from $\mathrm{Me}$ and $\mathrm{Ph}$ to $\mathrm{C}_{6} \mathrm{H}_{4}-4-\mathrm{NO}_{2}$ to $\mathrm{CF}_{3}$ to 'tune' the acidity of the proton-ionizable side arm.

The metal cation complexing abilities of the 15 new proton-ionizable lariat ethers were assessed by competitive solvent extractions of five alkali metal cation species from aqueous solution into chloroform. All 15 compounds exhibited high $\mathrm{Na}^{+}$extraction selectivity consistent with threedimensional complexation of the metal ion by the polyether oxygens and the ionized side arm. For the three sym-(aryl)dibenzo-16-crown-5-oxyacetic acids, the extraction selectivity order was $\mathrm{Na}^{+}>\mathrm{K}^{+}>\mathrm{Li}^{+}, \mathrm{Rb}^{+}, \mathrm{Cs}^{+}$with $\mathrm{Na}^{+} / \mathrm{K}^{+}$selectivity ratios exceeding 100 , the upper limit for the 
ion chromatographic analytical method. This is an appreciably greater $\mathrm{Na}^{+}$extraction selectivity that that reported for sym-(decyl)dibenzo-16-crown-5-oxyacetic acid.

Within each of the three series of sym-(aryl)dibenzo-16-crown-5 compounds having $N$ (X)sulfonyl oxyacetamide side arms and a common aryl group, the extractant acidity, as assessed by $\mathrm{pH}_{0.5}$ (the $\mathrm{pH}$ of half metal ion loading) increased as $\mathrm{X}$ was varied in the order of $\mathrm{Me}, \mathrm{Ph}<$ $\mathrm{C}_{6} \mathrm{H}_{4}-4-\mathrm{NO}_{2}<\mathrm{CF}_{3}$ consistent with the electron-withdrawing ability of $\mathrm{X}$. Although extraction selectivity orders of $\mathrm{Na}^{+}>>\mathrm{K}^{+}>\mathrm{Li}^{+}, \mathrm{Rb}^{+}, \mathrm{Cs}^{+}$were again observed, the $\mathrm{Na}^{+} / \mathrm{K}^{+}$ratios were appreciably lower that those found for their lariat ether carboxylic acid analogues. This lower $\mathrm{Na}^{+}$selectivity may result from a larger size of the ionized group which makes three-dimensional complexation of the metal cation more difficult.

\section{Experimental Section}

General. Reagents were obtained from commercial suppliers and used directly, unless otherwise noted. THF was dried over sodium wire with benzophenone ketyl as an indicator. Magnesium turnings were dried in an oven overnight before use. $\mathrm{Et}_{3} \mathrm{~N}$ and DMSO were stored over $4 \AA$ molecular sieves. The sym-(hydroxyl)dibenzo-16-crown-5 was prepared by a reported method. ${ }^{16}$ Infrared spectral analyses were performed with a Perkin-Elmer 1600 FT-IR spectrophotometer as deposits from $\mathrm{CH}_{2} \mathrm{Cl}_{2}$ solutions on a $\mathrm{NaCl}$ plate. The absorptions are given in wavenumbers $\left(\mathrm{cm}^{-}\right.$ ${ }^{1}$ ). NMR spectra were measured in $\mathrm{CDCl}_{3}$ with a Varian Unity Inova FT-500 spectrometer (499.7 $\mathrm{MHz}$ for ${ }^{1} \mathrm{H}, 125.7 \mathrm{MHz}$ for ${ }^{13} \mathrm{C}$ ) at $296 \mathrm{~K}$. Chemical shifts $(\delta)$ are expressed in ppm downfield from TMS and coupling constants $(J)$ values are given in Hz. Melting points were determined with a Mel-Temp melting point apparatus. Elemental analysis was performed by Desert Analytics Laboratory (now Columbia Analytical Services) of Tucson, Arizona.

sym-(Keto)dibenzo-16-crown-5 (2) (improved synthesis). Oxalyl chloride (3.92 mL, $45 \mathrm{mmol})$ and $\mathrm{CH}_{2} \mathrm{Cl}_{2}(65 \mathrm{~mL})$ were added to a 3-necked flask in a hood. A nitrogen purge was started and the flask was placed in a Dry Ice-acetone bath. DMSO $(4.25 \mathrm{~mL}, 60 \mathrm{mmol})$ was added with a syringe pump at a rate of $1 \mathrm{~mL} / \mathrm{min}$. After $10 \mathrm{~min}$, a solution of lariat ether alcohol 1 (5.19 g, 15 $\mathrm{mmol})$ in $\mathrm{CH}_{2} \mathrm{Cl}_{2}(20 \mathrm{~mL})$ was added dropwise. The solution was stirred for $30 \mathrm{~min}$ and then $\mathrm{Et}_{3} \mathrm{~N}(20.91 \mathrm{~mL}, 150 \mathrm{mmol})$ was added dropwise. After $30 \mathrm{~min}$, the Dry Ice-acetone bath was replaced with an ice-water bath and stirring was continued for $15 \mathrm{~min}$. The solution was diluted with $\mathrm{CH}_{2} \mathrm{Cl}_{2}(25 \mathrm{~mL})$ and then $\mathrm{H}_{2} \mathrm{O}(25 \mathrm{~mL})$ was added to quench the reaction. After separation, the aqueous layer was extracted with $\mathrm{CH}_{2} \mathrm{Cl}_{2}(25 \mathrm{~mL})$. The organic layers were combined and washed with $5 \%$ aq $\mathrm{HCl}(3 \times 125 \mathrm{~mL}), \mathrm{H}_{2} \mathrm{O}(125 \mathrm{~mL}), 1.05 \%$ diluted commercial bleach $(125$ $\mathrm{mL})$, commercial bleach $(5.25 \%, 125 \mathrm{~mL})$, satd aq $\mathrm{Na}_{2} \mathrm{SO}_{3}(2 \times 125 \mathrm{~mL})$, and $\mathrm{H}_{2} \mathrm{O}(2 \times 125 \mathrm{~mL})$. The organic layer was dried over $\mathrm{MgSO}_{4}$ and evaporated in vacuo to give a pale yellow solid, which was chromatographed on silica gel with $\mathrm{CH}_{2} \mathrm{Cl}_{2}-\mathrm{EtOAc}(3: 2)$ as eluent and then 
recrystallized from THF-hexanes (3:1) to give $3.92 \mathrm{~g}$ (76\%) of white needles with mp 141-143 ${ }^{\circ} \mathrm{C}\left(1 \mathrm{it}{ }^{8} \mathrm{mp} 138-139{ }^{\circ} \mathrm{C}\right)$.

\section{General procedure for the synthesis of $\mathbf{s y m}$-(aryl)(hydroxy)dibenzo-16-crown-5 compounds 3 and 4}

Oven-dried magnesium turnings (1.06 g, $43.6 \mathrm{mmol})$ in THF (20 mL) were added to a 3-necked flask under nitrogen. A solution of the appropriate aryl bromide in THF $(20 \mathrm{~mL})$ was added dropwise via an addition funnel over a 0.5 -h period. The reaction was initiated by heating followed by stirring for $2 \mathrm{~h}$ at room temperature. Once the Grignard reagent had formed (indicated by a gray/green solution and the disappearance of $\mathrm{Mg}$ ), a solution of lariat ether ketone $2(5.00 \mathrm{~g}, 14.5 \mathrm{mmol})$ in THF $(50 \mathrm{~mL})$ was added dropwise over a 30 -min period. The mixture was stirred overnight and the reaction was quenched by addition of $5 \%$ aq $\mathrm{NH}_{4} \mathrm{Cl}(75$ $\mathrm{mL})$. The THF was evaporated in vacuo and the residue was extracted with $\mathrm{CH}_{2} \mathrm{Cl}_{2}(2 \times 75 \mathrm{~mL})$. The combined $\mathrm{CH}_{2} \mathrm{Cl}_{2}$ layers were dried over $\mathrm{MgSO}_{4}$ and evaporated in vacuo to give a white solid. The residue was purified by column chromatography or recrystallization.

sym-(Hydroxy)(1-naphthyl)dibenzo-16-crown-5 (3) was chromatographed on silica gel with EtOAc-hexanes $(1: 3)$ as eluent to give $6.50 \mathrm{~g}(95 \%)$ of white solid with $\mathrm{mp} 110{ }^{\circ} \mathrm{C}$. $v_{\max }$ $\left(\right.$ film) $/ \mathrm{cm}^{-1}: 3542(\mathrm{O}-\mathrm{H}), 1257,1060(\mathrm{C}-\mathrm{O}) . \delta_{\mathrm{H}} 3.92-4.04(\mathrm{~m}, 4 \mathrm{H}), 4.09(\mathrm{~s}, 1 \mathrm{H}), 4.13-4.27(\mathrm{~m}$, $4 \mathrm{H}), 4.68(\mathrm{~d}, J 10,2 \mathrm{H}), 4.87(\mathrm{~d}, J 10,2 \mathrm{H}), 6.77-6.84(\mathrm{~m}, 4 \mathrm{H}), 6.84-6.86(\mathrm{~m}, 1 \mathrm{H}), 6.86-6.88(\mathrm{~m}$, $1 \mathrm{H}), 6.88-6.95(\mathrm{~m}, 2 \mathrm{H}), 7.40-7.54(\mathrm{~m}, 3 \mathrm{H}), 7.76-7.90(\mathrm{~m}, 2 \mathrm{H}), 8.07(\mathrm{~d}, J 5,1 \mathrm{H}), 8.85(\mathrm{~d}, J 10$, $1 \mathrm{H}) . \delta_{\mathrm{C}} 68.0,69.8,75.1,78.3,114.2,118.2,121.5,122.9,124.7,125.0,125.5,126.6,126.8$, 129.2 , 129.5, 131.9, 134.9, 135.6, 148.6, 150.2. Found: C, 73.82; $\mathrm{H}, 6.05 \% . \mathrm{C}_{29} \mathrm{H}_{28} \mathrm{O}_{6}$ requires C, $73.71 ; \mathrm{H}, 5.97 \%$.

sym-(Hydroxy)(2-naphthyl)dibenzo-16-crown-5 (4) was chromatographed on silica gel with EtOAc-hexanes (1:3) as eluent to give $5.86 \mathrm{~g}(90 \%)$ of white solid with $\mathrm{mp} 135-136{ }^{\circ} \mathrm{C} . v_{\max }$ $\left(\right.$ film) $/ \mathrm{cm}^{-1}: 3508(\mathrm{O}-\mathrm{H}), 1257,1053(\mathrm{C}-\mathrm{O}) . \delta_{\mathrm{H}} 3.92(\mathrm{~s}, 1 \mathrm{H}), 3.96-4.07(\mathrm{~m}, 4 \mathrm{H}), 4.11-4.29(\mathrm{~m}$, $4 \mathrm{H}), 4.53(\mathrm{dd}, J 10,30,4 \mathrm{H}), 6.74-6.83(\mathrm{~m}, 4 \mathrm{H}), 6.83-6.89(\mathrm{~m}, 2 \mathrm{H}), 6.89-6.95(\mathrm{~m}, 2 \mathrm{H}), 7.39-7.52$ $(\mathrm{m}, 2 \mathrm{H}), 7.80-7.94(\mathrm{~m}, 4 \mathrm{H}), 8.28(\mathrm{~s}, 1 \mathrm{H}) . \delta_{\mathrm{C}} 67.9,69.8,76.0,76.4,114.0,118.3,121.5,123.0$, $124.3,124.5,125.8,127.5,127.6,128.3,132.8,133.3,138.9,148.7,150.2$. Found: C, 73.82; H, $6.00 \% . \mathrm{C}_{29} \mathrm{H}_{28} \mathrm{O}_{6}$ requires $\mathrm{C}, 73.71 ; \mathrm{H}, 5.97 \%$.

sym-(Hydroxy)(9-phenanthryl)dibenzo-16-crown-5 (18). Dry magnesium turnings (1.64 g, $67.5 \mathrm{mmol}$ ) were placed in an oven-dried, 3-necked flask equipped with a dropping funnel and a condenser under nitrogen. THF $(10 \mathrm{~mL})$ and a crystal of iodine were added to the flask. A solution of 9-bromophenanthrene $(15.42 \mathrm{~g}, 60 \mathrm{mmol})$ in THF $(70 \mathrm{~mL})$ was added over a 30-min period. The mixture was heated to initiate the reaction and then the mixture was stirred at room temperature. The reaction was completed when the color of the mixture turned yellow-brown (about $3 \mathrm{~h})$. A solution of $2(5.16 \mathrm{~g}, 15 \mathrm{mmol})$ in THF $(100 \mathrm{~mL})$ was added over a 2-h period. The mixture was stirred overnight. After cooling to $0{ }^{\circ} \mathrm{C}, 5 \%$ aq $\mathrm{NH}_{4} \mathrm{Cl}(30 \mathrm{~mL})$ was added to the flask dropwise. After stirring for $10 \mathrm{~h}$, the white solid was filtered. For the filtrate, the THF was 
evaporated in vacuo and the aqueous solution was extracted with $\mathrm{CH}_{2} \mathrm{Cl}_{2}(2 \times 50 \mathrm{~mL})$. The combined organic layers were dried over $\mathrm{MgSO}_{4}$ and evaporated in vacuo. The filtered solid and the additional solid recovered from the filtrate were combined and recrystallized from hexanesTHF (2:1) to obtain $6.40 \mathrm{~g}(82 \%)$ of white solid with $\mathrm{mp} 97-98{ }^{\circ} \mathrm{C}$. $v_{\max }$ (film) $/ \mathrm{cm}^{-1} 3528$ (br O$\mathrm{H}), 1264,1123,1043(\mathrm{C}-\mathrm{O}) . \delta_{\mathrm{H}} 4.07-4.01\left(\mathrm{~m}, 4 \mathrm{H}, \mathrm{OCH}_{2}\right), 4.12(\mathrm{~s}, 1 \mathrm{H}), 4.23(\mathrm{t}, J 4,4 \mathrm{H}), 4.80(\mathrm{~d}$, $J 10,2 \mathrm{H}), 4.97$ (d, $J 10,2 \mathrm{H},), 6.94-6.79(\mathrm{~m}, 8 \mathrm{H}), 7.67-7.56(\mathrm{~m}, 4 \mathrm{H}), 7.94(\mathrm{dd}, J 8,1,1 \mathrm{H}), 8.35$ (s, $1 \mathrm{H}), 8.67(\mathrm{~d}, J 8,1 \mathrm{H}), 8.77(\mathrm{dd}, J 8,2,1 \mathrm{H}), 9.00(\mathrm{~d}, J 8,1 \mathrm{H}) . \delta_{\mathrm{C}} 68.1,69.9,75.1,78.2,114.3$, $118.3,121.6,122.3,123.0,123.3,125.8,126.1,126.6,126.9,127.3,128.3,129.2,130.5,130.6$, 131.2, 131.6, 133.6, 148.7, 150.2. Found: $\mathrm{C}, 76.12 ; \mathrm{H}, 5.93 \% . \mathrm{C}_{33} \mathrm{H}_{30} \mathrm{O}_{6}$ requires $\mathrm{C}, 75.84 ; \mathrm{H}$, $5.79 \%$.

Methyl sym-(1-naphthyl)dibenzo-16-crown-5-oxyacetate (5). $\mathrm{NaH}(0.39 \mathrm{~g}, 16.9 \mathrm{mmol})$ and THF $(20 \mathrm{~mL})$ were added to a 3-necked flask. The mixture was stirred under nitrogen for $30 \mathrm{~min}$ and a solution of lariat ether alcohol $3(2.00 \mathrm{~g}, 4.33 \mathrm{mmol})$ dissolved in THF (20 mL) was added dropwise over a $1-\mathrm{h}$ period. After stirring for $1 \mathrm{~h}$, a solution of methyl bromoacetate $(0.80 \mathrm{~g}, 8.46$ $\mathrm{mmol})$ in THF $(50 \mathrm{~mL})$ was added dropwise over a 3-4-h period. The reaction mixture was stirred for an additional $10 \mathrm{~h}$ and then quenched by cooling to $0{ }^{\circ} \mathrm{C}$ and adding water $(20 \mathrm{~mL})$. The THF was evaporated in vacuo and water $(10 \mathrm{~mL})$ was added to the mixture. After extraction with $\mathrm{CH}_{2} \mathrm{Cl}_{2}(3 \times 25 \mathrm{~mL})$, the combined organic layers were dried over $\mathrm{MgSO}_{4}$ and evaporated in vacuo. The residue was purified by chromatography on silica gel with hexanes-Et ${ }_{2} \mathrm{O}(1: 1)$ then EtOAc as eluents to give $1.93 \mathrm{~g}(79 \%)$ of white solid with $\mathrm{mp} 67-68{ }^{\circ} \mathrm{C} . v_{\max }(\mathrm{film}) / \mathrm{cm}^{-1}: 1754$ $(\mathrm{C}=\mathrm{O}), 1249,1060(\mathrm{C}-\mathrm{O}) . \delta_{\mathrm{H}} 3.60-3.77(\mathrm{~m}, 3 \mathrm{H}), 3.86-4.10(\mathrm{~m}, 4 \mathrm{H}), 4.10-4.28(\mathrm{~m}, 4 \mathrm{H}), 4.55(\mathrm{~s}$, $1 \mathrm{H}), 4.63-4.77(\mathrm{~m}, 3 \mathrm{H}), 5.01(\mathrm{~d}, J 25,2 \mathrm{H}), 6.61-7.07(\mathrm{~m}, 8 \mathrm{H}), 7.41-7.57(\mathrm{~m}, 3 \mathrm{H}), 7.82-8.03(\mathrm{~m}$, $2 \mathrm{H}), 8.52(\mathrm{~d}, J 20,1 \mathrm{H}), 8.95(\mathrm{~d}, J 20,1 \mathrm{H}) . \delta_{\mathrm{C}} 51.6,64.5,67.6,69.9,74.5,84.4,113.4,113.5$, $117.6,121.3,122.8,124.6,125.1,125.7,126.3,129.3,129.7,130.5,131.8,134.7,148.1,150.2$, 171.7. Found: $\mathrm{C}, 70.88 ; \mathrm{H}, 5.93 \% . \mathrm{C}_{32} \mathrm{H}_{32} \mathrm{O}_{8}$ requires $\mathrm{C}, 70.66 ; \mathrm{H}, 5.96 \%$.

sym-(1-Naphthyl)dibenzo-16-crown-5-oxyacetic acid (6). A mixture of 5 (1.15 g, $2.11 \mathrm{mmol})$, THF $(10 \mathrm{~mL})$ and $10 \%$ aq $\mathrm{NaOH}(5 \mathrm{~mL})$ was stirred overnight at room temperature. The THF was evaporated in vacuo and the aqueous residue was acidified with $6 \mathrm{~N} \mathrm{HCl}$ to $\mathrm{pH} 1$. Additional $6 \mathrm{~N} \mathrm{HCl}(20 \mathrm{~mL})$ and $\mathrm{CH}_{2} \mathrm{Cl}_{2}(20 \mathrm{~mL})$ were added and the mixture was stirred overnight. The mixture was extracted with $\mathrm{CH}_{2} \mathrm{Cl}_{2}(3 \times 20 \mathrm{~mL})$. The combined organic layers were dried over $\mathrm{MgSO}_{4}$ and evaporated in vacuo. The residue was recrystallized from hexanes to give $1.03 \mathrm{~g}$ $(85 \%)$ of white solid with mp 98-99 ${ }^{\circ} \mathrm{C}$. $v_{\max }(\mathrm{film}) / \mathrm{cm}^{-1}: 1731(\mathrm{C}=\mathrm{O}), 1255,1058(\mathrm{C}-\mathrm{O}) . \delta_{\mathrm{H}}$ $3.75-3.99(\mathrm{~m}, 2 \mathrm{H}), 3.99-4.14(\mathrm{~m}, 2 \mathrm{H}), 4.14-4.28(\mathrm{~m}, 4 \mathrm{H}), 4.68(\mathrm{~s}, 2 \mathrm{H}), 4.89$ (dd, J 30, 10, 4H), 6.75-6.83 (m, 4H), 6.83-6.91 (m, 2H), 6.91-7.01 (m, 2H), 7.42-7.54 (m, 2H), 7.54-7.62 (m, 1H), $7.91(\mathrm{~d}, J 10,2 \mathrm{H}) 8.02(\mathrm{~d}, J 5,1 \mathrm{H}), 8.64-8.80(\mathrm{~m}, 1 \mathrm{H}) . \delta_{\mathrm{C}} 113.0,117.4,121.1,123.1,124.7$, $125.4,125.5,126.6,128.4,129.5,130.6,131.6,132.0,134.8,147.6,150.2$, 172.8. Found: C, $68.53 ; \mathrm{H}, 5.58 \% . \mathrm{C}_{31} \mathrm{H}_{30} \mathrm{O}_{8}$ requires $\mathrm{C}, 68.21 ; \mathrm{H}, 5.57 \%$. 
General procedure for the synthesis of $N$-(X)sulfonyl sym-(1-naphthyl)dibenzo-16-crown-5oxyacetamides 10-13

Benzene $(50 \mathrm{~mL}), 6(1.20 \mathrm{~g}, 2.26 \mathrm{mmol})$ and oxalyl chloride $(1.20 \mathrm{~mL}, 13.56 \mathrm{mmol})$ were combined in a 1-necked flask and stirred at room temperature for $1.5 \mathrm{~h}$. The benzene was evaporated in vacuo and an IR spectrum of the residue was taken. Disappearance of the $\mathrm{C}=\mathrm{O}$ peak at $1731 \mathrm{~cm}^{-1}$ and appearance of a $\mathrm{C}=\mathrm{O}$ peak at $1824 \mathrm{~cm}^{-1}$ verified formation of acid chloride 8. The sulfonamide salt was prepared under nitrogen by adding $\mathrm{NaH}$ (0.54 g, $22.6 \mathrm{mmol})$ and THF $(20 \mathrm{~mL})$ to a 3-necked flask. A solution of the appropriate sulfonamide $(2.71 \mathrm{mmol})$ in THF $(20 \mathrm{~mL})$ was added over a 10-min period. The mixture was stirred at room temperature for $1.5 \mathrm{~h}$ followed by the dropwise addition of a solution of the acid chloride 8 in THF (20 mL). The reaction mixture was stirred overnight $\left(3 \mathrm{~h}\right.$ when $\left.\mathrm{X}=\mathrm{C}_{6} \mathrm{H}_{4}-4-\mathrm{NO}_{2}\right)$ at room temperature and cooled to $0{ }^{\circ} \mathrm{C}$. Water $(15 \mathrm{~mL})$ was added dropwise to destroy the excess $\mathrm{NaH}$. The THF was evaporated in vacuo and then $40 \mathrm{~mL}$ of distilled water was added to the residue. The mixture was extracted with $\mathrm{CH}_{2} \mathrm{Cl}_{2}(100 \mathrm{~mL}$ then $50 \mathrm{~mL})$. The combined organic extracts were washed with $10 \%$ aq $\mathrm{K}_{2} \mathrm{CO}_{3}(2 \times 50 \mathrm{~mL})$. The combined aq layers were extracted with $\mathrm{CH}_{2} \mathrm{Cl}_{2}(2 \times 50 \mathrm{~mL})$. The combined organic layers were dried over $\mathrm{MgSO}_{4}$ and evaporated in vacuo to give a solid that was purified by chromatography and recrystallization.

$N$-Methanesulfonyl sym-(1-naphthyl)dibenzo-16-crown-5-oxyacetamide (10) was chromatographed on alumina with EtOAc-hexanes (1:1) as eluent. Recrystallization from the same solvent gave $0.82 \mathrm{~g}(75 \%)$ of white solid with $\mathrm{mp} 100{ }^{\circ} \mathrm{C} . v_{\max }($ film $) / \mathrm{cm}^{-1}: 3342(\mathrm{~N}-\mathrm{H})$, $1723(\mathrm{C}=\mathrm{O}), 1257,1061(\mathrm{C}-\mathrm{O}), 1343,1158\left(\mathrm{SO}_{2}\right) . \delta_{\mathrm{H}} 3.09(\mathrm{~s}, 3 \mathrm{H}), 3.85-3.99(\mathrm{~m}, 2 \mathrm{H}), 4.02-4.15$ $(\mathrm{m}, 2 \mathrm{H}), 4.15-4.28(\mathrm{~m}, 4 \mathrm{H}), 4.80(\mathrm{~s}, 2 \mathrm{H}), 4.91(\mathrm{dd}, J 10,30,4 \mathrm{H}), 6.74-7.84(\mathrm{~m}, 4 \mathrm{H}), 6.84-6.91$ $(\mathrm{m}, 2 \mathrm{H}), 6.91-6.99(\mathrm{~m}, 2 \mathrm{H}), 7.45-7.59(\mathrm{~m}, 3 \mathrm{H}), 7.86-7.94(\mathrm{~m}, 3 \mathrm{H}), 8.71(\mathrm{~d}, J 10,1 \mathrm{H}), 9.52(\mathrm{~s}$, $1 \mathrm{H}) . \delta_{\mathrm{C}}: 41.1,65.9,67.1,69.3,72.1,84.5,112.7,117.6,121.1,123.3,124.8,125.6,126.6,127.2$, 129.6, 130.3, 131.6, 132.4, 147.4, 150.2, 170.8. Found: C, 63.38; H, 5.21; N, 2.55. $\mathrm{C}_{32} \mathrm{H}_{33} \mathrm{NO}_{9} \mathrm{~S}$ requires $\mathrm{C}, 63.25 ; \mathrm{H}, 5.47 ; \mathrm{N}, 2.30 \%$.

$\mathrm{N}$-Benzenesulfonyl sym-(1-naphthyl)dibenzo-16-crown-5-oxyacetamide (11) was chromatographed on alumina with EtOAc-hexanes (1:1) as eluent followed by recrystallization from the same solvent to give $0.65 \mathrm{~g}(65 \%)$ of white solid with $\mathrm{mp} 100{ }^{\circ} \mathrm{C} . v_{\max }(\mathrm{film}) / \mathrm{cm}^{-1}: 3332(\mathrm{~N}-\mathrm{H})$, $1723(\mathrm{C}=\mathrm{O}), 1257,1060(\mathrm{C}-\mathrm{O})$; 1353, $1160\left(\mathrm{SO}_{2}\right) . \delta_{\mathrm{H}} 3.78-3.87(\mathrm{~m}, 2 \mathrm{H}), 3.91-4.00(\mathrm{~m}, 2 \mathrm{H})$, 4.00-4.08 (m, 2H), 4.09-4.21 (m, 2H), $4.71(\mathrm{~s}, 2 \mathrm{H}), 4.65-4.75(\mathrm{dd}, J 20,11,4 \mathrm{H}), 6.70-7.75(\mathrm{~m}$, $2 \mathrm{H}), 6.75-6.85(\mathrm{~m}, 4 \mathrm{H}), 6.88-6.99(\mathrm{~m}, 2 \mathrm{H}), 7.27-7.36(\mathrm{~m}, 2 \mathrm{H}), 7.43-7.59(\mathrm{~m}, 4 \mathrm{H}), 7.80-7.95(\mathrm{~m}$, $5 \mathrm{H}) 8.64(\mathrm{t}, J 3,1 \mathrm{H}), 9.67(\mathrm{~s}, 1 \mathrm{H}) . \delta_{\mathrm{C}} 65.7,67.0,69.4,71.6,76.4,84.2,112.5,117.4,120.9$, $123.2,124.7,125.5,125.7,126.9,128.3,128.5,129.5,130.2,131.5,132.7,133.4,134.9,138.8$, 147.3, 150.2, 169.5. Found: C, 66.15; H, 5.18; N, 2.28\%. $\mathrm{C}_{37} \mathrm{H}_{35} \mathrm{NO}_{9} \mathrm{~S}$ requires $\mathrm{C}, 66.35 ; \mathrm{H}, 5.27$; $\mathrm{N}, 2.09 \%$.

$\boldsymbol{N}$-(4-Nitrobenzene)sulfonyl sym-(1-naphthyl)dibenzo-16-crown-5-oxyacetamide (12) was chromatographed on alumina with EtOAc-hexanes (1:1) as eluent. Recrystallization from the same solvent gave $0.64 \mathrm{~g}(55 \%)$ of yellow solid with $\mathrm{mp} 125-126{ }^{\circ} \mathrm{C} . v_{\max }(\mathrm{film}) / \mathrm{cm}^{-1}: 3474(\mathrm{~N}-$ $\mathrm{H}), 1729(\mathrm{C}=\mathrm{O}), 1254,1062(\mathrm{C}-\mathrm{O}), 1348,1127\left(\mathrm{SO}_{2}\right) . \delta_{\mathrm{H}} 3.71-3.93(\mathrm{~m}, 2 \mathrm{H}), 3.94-4.09(\mathrm{~m}, 2 \mathrm{H})$, 
4.09-4.21 (m, 2H), $4.76(\mathrm{~s}, 2 \mathrm{H}), 4.83(\mathrm{dd}, J 10,30,4 \mathrm{H}), 6.66-6.76(\mathrm{~m}, 2 \mathrm{H}), 6.76-7.85(\mathrm{~m}, 4 \mathrm{H})$, 6.92-7.01 (m, 2H) 7.43-7.52 (m, 2H), $7.55(\mathrm{t}, J 15,1 \mathrm{H}), 7.80(\mathrm{~d}, J 5,1 \mathrm{H}), 7.87-7.94(\mathrm{~m}, 2 \mathrm{H})$, 7.94-7.99 (m, 2H), 7.99-8.05 (m, 2H), 8.55-8.73 (m, 1H), 9.81 (s, 1H). $\delta_{\mathrm{C}} 65.6,67.0,69.3,71.4$, $84.4,112.4,117.5,121.0,123.4,123.6,124.7,125.6,125.8,126.5,129.6,130.4,131.5,132.6$, 135.0, 144.1, 147.2, 150.1, 150.3, 168.9. Found: C, 56.64; H, 4.48; N, 3.57\%. $\mathrm{C}_{37} \mathrm{H}_{34} \mathrm{~N}_{2} \mathrm{O}_{11} \mathrm{~S} \bullet 1.1 \mathrm{CH}_{2} \mathrm{Cl}_{2}$ requires $\mathrm{C}, 58.84 ; \mathrm{H}, 4.56 ; \mathrm{N}, 3.70 \%$.

$\mathrm{N}$-Trifluoromethanesulfonyl sym-(1-naphthyl)dibenzo-16-crown-5-oxyacetamide (13) was chromatographed on alumina with EtOAc-hexanes (1:1) as eluent. Recrystallization from the same solvent gave $0.95 \mathrm{~g}(69 \%)$ of white solid with $\mathrm{mp} 125-126{ }^{\circ} \mathrm{C} . v_{\max }($ film $) / \mathrm{cm}^{-1}: 3296(\mathrm{~N}-\mathrm{H})$, $1754(\mathrm{C}=\mathrm{O}), 1256,1061(\mathrm{C}-\mathrm{O}), 1343,1136\left(\mathrm{SO}_{2}\right) . \delta_{\mathrm{H}} 3.82-3.95(\mathrm{~m}, 2 \mathrm{H}), 3.95-4.10(\mathrm{~m}, 2 \mathrm{H})$, 4.10-4.28 (m, 4H), $4.83(\mathrm{~d}, J 10,2 \mathrm{H}), 4.95(\mathrm{~d}, J 10,2 \mathrm{H}), 5.03(\mathrm{~s}, 2 \mathrm{H}), 6.71-6.84(\mathrm{~m}, 4 \mathrm{H}), 6.84-$ $6.91(\mathrm{~m}, 2 \mathrm{H}), 6.91-7.03(\mathrm{~m}, 2 \mathrm{H}), 7.45-7.55(\mathrm{~m}, 2 \mathrm{H}), 7.59(\mathrm{t}, J 15,3 \mathrm{H}), 7.84(\mathrm{~d}, J 5,1 \mathrm{H}), 7.90-$ $7.98(\mathrm{~m}, 2 \mathrm{H}), 8.55-8.69(\mathrm{~m}, 1 \mathrm{H}), 10.12(\mathrm{~s}, 1 \mathrm{H}) . \delta_{\mathrm{C}} 66.2,67.0,69.3,71.5,84.4,112.5,117.4$, $117.8,120.3,121.0,123.5,124.8,125.6,126.6,129.6,130.4,132.4,135.0,147.1,150.1,169.0$. Found: C, 57.96; H, 4.71; N, 1.96\%. $\mathrm{C}_{32} \mathrm{H}_{30} \mathrm{~F}_{3} \mathrm{NO}_{9}$ S requires: $\mathrm{C}, 58.09 ; \mathrm{H}, 4.57 ; \mathrm{N}, 2.12 \%$.

sym-(2-Naphthy1)dibenzo-16-crown-5-oxyacetic acid (7). $\mathrm{NaH}(0.53 \mathrm{~g}, 21.2 \mathrm{mmol})$ and THF $(20 \mathrm{~mL})$ were added to a 3-necked flask. The mixture was stirred under nitrogen for $30 \mathrm{~min}$ and then a solution of alcohol $4(1.05 \mathrm{~g}, 2.12 \mathrm{mmol})$ in THF $(20 \mathrm{~mL})$ was added dropwise during a 1$\mathrm{h}$ period. The mixture was stirred for an additional $1 \mathrm{~h}$ and a solution of bromoacetic acid $(0.45 \mathrm{~g}$, $3.18 \mathrm{mmol})$ in THF $(50 \mathrm{~mL})$ was added dropwise over a 3-4-h period. The mixture was stirred for an additional $10 \mathrm{~h}$ and cooled to $0{ }^{\circ} \mathrm{C}$ with an ice-water bath. Water $(10 \mathrm{~mL})$ was added and the THF was evaporated in vacuo. Additional water $(25 \mathrm{~mL})$ was added and the mixture was acidified with $6 \mathrm{~N} \mathrm{HCl}$ to give a white solid, which was dried with a benzene azeotrope. The resulting solid was recrystallized from hexanes to give $2.10 \mathrm{~g}(92 \%)$ of a white solid with $\mathrm{mp}$ 228-229 ${ }^{\circ} \mathrm{C} . v_{\max }(\mathrm{film}) / \mathrm{cm}^{-1}(\mathrm{KBr}): 1734(\mathrm{C}=\mathrm{O}), 1255,1025(\mathrm{C}-\mathrm{O}) . \delta_{\mathrm{H}}\left(\left(\mathrm{CD}_{3}\right)_{2} \mathrm{SO}\right): 3.83-4.00(\mathrm{~m}$, $4 \mathrm{H}), 4.04-4.21(\mathrm{~m}, 4 \mathrm{H}), 4.48(\mathrm{~d}, J 10,4 \mathrm{H}), 4.60(\mathrm{~d}, J 10,2 \mathrm{H}), 6.71-6.87(\mathrm{~m}, 4 \mathrm{H}), 6.86-7.02(\mathrm{~m}$, $4 \mathrm{H}), 7.46-7.59(\mathrm{~m}, 2 \mathrm{H}), 7.88-8.01(\mathrm{~m}, 4 \mathrm{H}), 8.27(\mathrm{~s}, 1 \mathrm{H}), 12.60(\mathrm{~s}, 1 \mathrm{H}) . \delta_{\mathrm{C}}\left(\left(\mathrm{CD}_{3}\right)_{2} \mathrm{SO}\right): 39.0,39.2$, 39.3 , 39.5, 39.7, 39.8, 39.9, 40.0, 40.1, 63.0, 67.0, 68.9, 73.4, 81.2, 112.7, 117.3, 120.7, 122.8, $125.6,126.0,126.1,127.2,127.4,128.0,132.3,132.6,137.2,147.2,149.8,172.0$. Found: C, $68.35 ; \mathrm{H}, 5.44 \% . \mathrm{C}_{31} \mathrm{H}_{30} \mathrm{O}_{8}$ requires $\mathrm{C}, 68.24 ; \mathrm{H}, 5.63 \%$.

General procedure for the synthesis of $N$-(X)sulfonyl sym-(2-naphthyl)dibenzo-16-crown-5oxyacetamides 14-17

Benzene $(50 \mathrm{~mL})$, carboxylic acid 7 (0.74 g, $1.39 \mathrm{mmol})$, oxalyl chloride $(0.74 \mathrm{~mL}, 8.46 \mathrm{mmol})$, and DMF (1 drop) were added to a 1-necked flask. The solution was stirred under reflux for $1.5 \mathrm{~h}$ and evaporated in vacuo. The residue was analyzed by IR spectroscopy. A carbonyl peak at 1824 $\mathrm{cm}^{-1}$ indicated completion of the reaction. The sulfonamide salt was prepared by adding $\mathrm{NaH}$ $(0.17 \mathrm{~g}, 7.05 \mathrm{mmol})$ and THF $(20 \mathrm{~mL})$ to a 3-necked flask under nitrogen. A solution of the appropriate sulfonamide $(1.69 \mathrm{mmol})$ in THF $(20 \mathrm{~mL})$ was added dropwise via an addition funnel. The mixture was stirred for $1.5 \mathrm{~h}$ at room temperature. A solution of acid chloride 9 in 
THF $(20 \mathrm{~mL})$ was added dropwise and the mixture was stirred overnight $\left(3 \mathrm{~h}\right.$ when $\mathrm{X}=\mathrm{C}_{6} \mathrm{H}_{4}-4$ $\left.\mathrm{NO}_{2}\right)$. After cooling to $0{ }^{\circ} \mathrm{C}$, water $(15 \mathrm{~mL})$ was added dropwise to destroy the excess $\mathrm{NaH}$. The THF was evaporated in vacuo and water $(40 \mathrm{~mL})$ was added to the residue. The mixture was extracted with $\mathrm{CH}_{2} \mathrm{Cl}_{2}(100 \mathrm{~mL}$ then $50 \mathrm{~mL})$. The combined organic extracts were washed with $10 \%$ aq $\mathrm{K}_{2} \mathrm{CO}_{3}(2 \times 50 \mathrm{~mL})$. The aqueous washes were back extracted with $\mathrm{CH}_{2} \mathrm{Cl}_{2}(2 \times 50 \mathrm{~mL})$. The organic extracts and back extracts were combined, dried over $\mathrm{MgSO}_{4}$, and evaporated in vacuo. The residue was dissolved in $\mathrm{CH}_{2} \mathrm{Cl}_{2}$ and the sulfonyl salt precipitated. The product was acidified with $3 \mathrm{~N} \mathrm{HCl}$ to $\mathrm{pH} 1$. The organic layer was separated, washed with distilled water $(2 \times 50 \mathrm{~mL})$, dried over $\mathrm{MgSO}_{4}$, and evaporated in vacuo.

$\boldsymbol{N}$-Methanesulfonyl sym-(2-naphthyl)dibenzo-16-crown-5-oxyacetamide (14) was recrystallized from EtOAc-hexanes to give $0.36 \mathrm{~g}(42 \%)$ of white solid with $\mathrm{mp} 111-112{ }^{\circ} \mathrm{C}$. $v_{\max }$ (film) $/ \mathrm{cm}^{-1}: 3420(\mathrm{~N}-\mathrm{H}), 1719(\mathrm{C}=\mathrm{O}), 1256,1061(\mathrm{C}-\mathrm{O}), 1343,1127\left(\mathrm{SO}_{2}\right) . \delta_{\mathrm{H}} 3.09(\mathrm{~s}, 3 \mathrm{H})$, 3.89-3.93 (m, 4H), 4.06-4.11 (m, 4H), 4.15-4.25 (m, 7H), $4.39(\mathrm{~d}, J 10,2 \mathrm{H}), 4.92(\mathrm{~d}, J 10 \mathrm{H}), 5.05$ $(\mathrm{s}, 2 \mathrm{H}), 6.71-6.73(\mathrm{~m}, 3 \mathrm{H}), 6.79-6.87(\mathrm{~m}, 3 \mathrm{H}), 6.84-6.87(\mathrm{~m}, 4 \mathrm{H}), 6.94-6.96(\mathrm{~m}, 4 \mathrm{H}), 7.54-7.56$ $(\mathrm{m}, 3 \mathrm{H}), 7.70-7.72(\mathrm{~m}, 2 \mathrm{H}), 7.89-7.97(\mathrm{~m}, 5 \mathrm{H}), 8.14(\mathrm{~s}, 1 \mathrm{H}), 9.56(\mathrm{~s}, 1 \mathrm{H}) . \delta_{\mathrm{C}} 41.1,66.1,66.9$, 69.4, 73.0, 82.4, 112.3, 117.4, 121.0, 123.4, 123.7, 125.8, 126.4, 126.5, 127.6, 128.4, 132.9, 133.2, 136.2, 147.2, 150.2, 171.6. Found: C, 63.19; H, 5.59; N, 2.69\%. $\mathrm{C}_{32} \mathrm{H}_{33} \mathrm{NO}_{9} \mathrm{~S}$ requires $\mathrm{C}$, $63.26 ; \mathrm{H}, 5.47 ; \mathrm{N}, 2.30 \%$.

$\mathrm{N}$-Benzenesulfonyl sym-(2-naphthyl)dibenzo-16-crown-5-oxyacetamide (15) was recrystallized from EtOAc-hexanes to give $0.46 \mathrm{~g}(53 \%)$ of white solid with $\mathrm{mp} 99-100{ }^{\circ} \mathrm{C} . v_{\max }$ (film) $/ \mathrm{cm}^{-1}: 3335(\mathrm{~N}-\mathrm{H}), 1731(\mathrm{C}=\mathrm{O}), 1246,1060(\mathrm{C}-\mathrm{O}), 1350,1125\left(\mathrm{SO}_{2}\right) . \delta_{\mathrm{H}} 3.63-3.78(\mathrm{~m}$, 2H), 3.78-3.97 (m, 4H), 3.99-4.15 (m, 2H), $4.30(\mathrm{~d}, J 15,2 \mathrm{H}), 4.85(\mathrm{~d}, J 10,2 \mathrm{H}), 4.95(\mathrm{~s}, 2 \mathrm{H})$, 6.61-6.73 (m, 2H), 6.73-6.84 (m, 4H), 6.91-7.03 (m, 2H), 7.25-7.36 (m, 2H), 7.43-7.52 (m, 1H), 7.52-7.60 (m, 2H), $7.71(\mathrm{dd}, J 10,10,1 \mathrm{H}), 7.77-7.87(\mathrm{~m}, 2 \mathrm{H}), 7.87-8.03(\mathrm{~m}, 3 \mathrm{H}), 8.14(\mathrm{~s}, 1 \mathrm{H})$, $9.72(\mathrm{~s}, 1 \mathrm{H}) . \delta_{\mathrm{C}}: 66.2,66.8,69.3,72.5,82.1,112.1,117.3,120.9,123.3,123.6,126.4,127.5$, 128.4, 132.9, 133.9, 136.5, 138.9, 147.0, 150.1, 170.1. Found: C, 66.26; H, 5.24; N, 2.18\%. $\mathrm{C}_{37} \mathrm{H}_{35} \mathrm{NO}_{9} \mathrm{~S}$ requires $\mathrm{C}, 66.35 ; \mathrm{H}, 5.27 ; \mathrm{N}, 2.09 \%$.

$\mathrm{N}$-(4-Nitrobenzene)sulfonyl sym-(2-naphthyl)dibenzo-16-crown-5-oxyacetamide (16) was chromatographed on alumina with $\mathrm{MeOH}-\mathrm{CH}_{2} \mathrm{Cl}_{2}(1: 10)$ as eluent. Recrystallization of the product from EtOAc-hexanes gave $0.37 \mathrm{~g}(37 \%)$ of yellow solid with $\mathrm{mp} 104-105{ }^{\circ} \mathrm{C} . v_{\max }$ (film) $/ \mathrm{cm}^{-1}: 3335(\mathrm{~N}-\mathrm{H}), 1731(\mathrm{C}=\mathrm{O}), 1246,1044(\mathrm{C}-\mathrm{O}), 1350,1127\left(\mathrm{SO}_{2}\right) . \delta_{\mathrm{H}} 3.73-3.84(\mathrm{~m}$, $2 \mathrm{H}), 3.85-3.96(\mathrm{~m}, 4 \mathrm{H}), 4.06-4.13(\mathrm{~m}, 2 \mathrm{H}), 4.27(\mathrm{~d}, J 10,2 \mathrm{H}), 4.78(\mathrm{~d}, J 10,2 \mathrm{H}), 5.00(\mathrm{~s}, 2 \mathrm{H})$, 6.62-6.71 (m, 2H), 6.71-6.76 (m, 2H), 6.76-6.84 (m, 2H), 6.92-7.02 (m, 2H), 7.52-7.61 (m, 2H), 7.66-7.71 (dd, $J 10,10,1 \mathrm{H}), 7.88-7.99(\mathrm{~m}, 7 \mathrm{H}), 8.14(\mathrm{~s}, 1 \mathrm{H}), 9.80(\mathrm{~s}, 1 \mathrm{H}) . \delta_{\mathrm{C}} 66.1,66.8,69.2$, $72.4,82.3,112.0,117.4,121.0,123.4,123.5,125.5,126.6,127.6,128.4,128.5,129.5,133.0$, 133.2, 136.4, 144.1, 150.0, 150.2, 170.4. Found: C, 62.11; H, 4.71; N, 4.21\%. $\mathrm{C}_{37} \mathrm{H}_{34} \mathrm{~N}_{2} \mathrm{O}_{11} \mathrm{~S}$ requires $\mathrm{C}, 62.18 ; \mathrm{H}, 4.79 ; \mathrm{N}, 3.92 \%$.

$\mathrm{N}$-Trifluoromethanesulfonyl sym-(2-naphthyl)dibenzo-16-crown-5-oxyacetamide (15) was recrystallized from EtOAc-hexanes to give $0.60 \mathrm{~g}(65 \%)$ of white solid with $\mathrm{mp} 78-79{ }^{\circ} \mathrm{C}$. $v_{\max }$ (film) $/ \mathrm{cm}^{-1}: 3420(\mathrm{~N}-\mathrm{H}), 1758(\mathrm{C}=\mathrm{O}), 1256,1065(\mathrm{C}-\mathrm{O}), 1385,1136\left(\mathrm{SO}_{2}\right) . \delta_{\mathrm{H}} 3.77-3.92(\mathrm{~m}$, 
2H), 3.93-4.05 (m, 2H), 4.10-4.18 (m, 2H), 4.18-4.26 (m, 2H), 4.25-4.36 (m, 2H), 4.90-5.01 (m, $2 \mathrm{H}), 5.23(\mathrm{~s}, 2 \mathrm{H}), 6.65-6.74(\mathrm{~m}, 2 \mathrm{H}), 6.76-6.82(\mathrm{~m}, 2 \mathrm{H}), 6.82-6.91(\mathrm{~m}, 2 \mathrm{H}), 6.92-7.02(\mathrm{~m}, 2 \mathrm{H})$, 7.51-7.60 (m, 2H), $7.69(\mathrm{dd}, J 10,10,1 \mathrm{H}), 7.87-7.96(\mathrm{~m}, 2 \mathrm{H}), 8.16(\mathrm{~d}, J 5,1 \mathrm{H}), 8.16(\mathrm{~s}, 1 \mathrm{H})$, $10.14(\mathrm{~s}, 1 \mathrm{H}) . \delta_{\mathrm{C}}: 66.7,66.8,69.7,72.5,82.3,112.1,117.2,121.0,123.3,123.6,125.6,126.6$, 127.6, 128.4, 128.5, 133.0, 133.2, 136.2, 146.7, 150.1, 169.5. Found: C, 58.11; H, 4.76; N, $2.24 \% . \mathrm{C}_{32} \mathrm{H}_{30} \mathrm{~F}_{3} \mathrm{NO}_{9} \mathrm{~S}$ requires $\mathrm{C}, 58.09 ; \mathrm{H}, 4.57 ; \mathrm{N}, 2.12 \%$.

sym-(9-Phenanthryl)dibenzo-16-crown-5-oxyacetic acid (19). $\mathrm{NaH}$ (1.20 g, $50 \mathrm{mmol})$ and THF $(30 \mathrm{~mL})$ were added to a 1-necked flask. After the mixture was stirred for 30 min under nitrogen, a solution of lariat ether alcohol 18 (5.23 g, $10 \mathrm{mmol})$ in THF (80 mL) was added over a $1-\mathrm{h}$ period. The mixture was stirred for $1 \mathrm{~h}$ and ethyl bromoacetate $(3.34 \mathrm{~g}, 20 \mathrm{mmol})$ in THF $\left(70 \mathrm{~mL}\right.$ ) was added over a 2-h period. The mixture was stirred overnight and quenched with $\mathrm{H}_{2} \mathrm{O}$ $(20 \mathrm{~mL})$ at $0{ }^{\circ} \mathrm{C}$. After the THF was evaporated in vacuo, $\mathrm{H}_{2} \mathrm{O}(10 \mathrm{~mL})$ was added to the residue. The solid was filtered. The filtrate was extracted with $\mathrm{CH}_{2} \mathrm{Cl}_{2}(2 \times 50 \mathrm{~mL})$. After separation, the filtered solid was dissolved in the combined organic $\mathrm{CH}_{2} \mathrm{Cl}_{2}$ layers. The resultant $\mathrm{CH}_{2} \mathrm{Cl}_{2}$ solution was dried over $\mathrm{MgSO}_{4}$ and evaporated in vacuo. After chromatography on silica gel with $\mathrm{CH}_{2} \mathrm{Cl}_{2}-\mathrm{MeOH}$ (4:1) as eluent, the product was dissolved in $\mathrm{CH}_{2} \mathrm{Cl}_{2}$ and the resulting solution was shaken with $1 \mathrm{~N} \mathrm{HCl}$ to obtain $5.30 \mathrm{~g} \mathrm{(91 \% )} \mathrm{of} \mathrm{white} \mathrm{solid} \mathrm{with} \mathrm{a} \mathrm{melting} \mathrm{point} \mathrm{of}$ 101-102 ${ }^{\circ} \mathrm{C} . v_{\max }\left(\right.$ film) $/ \mathrm{cm}^{-1} 3373$ (br $\left.\mathrm{CO}_{2} \mathrm{H}\right), 1726(\mathrm{C}=\mathrm{O}), 1264,1126,1051(\mathrm{C}-\mathrm{O}) . \delta_{\mathrm{H}} 3.94-$ $3.91(\mathrm{~m}, 2 \mathrm{H}), 4.11-4.07(\mathrm{~m}, 2 \mathrm{H}), 4.24-4.15(\mathrm{~m}, 4 \mathrm{H}), 4.68(\mathrm{~s}, 2 \mathrm{H}), 5.00(\mathrm{~s}, 4 \mathrm{H}), 6.98-6.78(\mathrm{~m}, 8 \mathrm{H})$, 7.74-7.59 (m, 4H), $7.98(\mathrm{dd}, J 8,1,1 \mathrm{H}), 8.31(\mathrm{~s}, 1 \mathrm{H}), 8.70(\mathrm{~d}, J 8,1 \mathrm{H}), 8.82-8.80(\mathrm{~m}, 2 \mathrm{H}), 10.08$ (br s, $1 \mathrm{H}) . \delta_{\mathrm{C}} 64.2,67.5,69.5,73.0,84.7,113.1,117.5,121.2,122.5,123.2,123.6,126.3,126.3$, $127.0,127.0,127.7,129.2,130.0,130.1,130.8,130.8,131.6,147.6,150.3,172.0$. Found: C, 72.10; H, 5.37\%. $\mathrm{C}_{35} \mathrm{H}_{32} \mathrm{O}_{8}$ requires $\mathrm{C}, 72.40 ; \mathrm{H}, 5.56 \%$.

\section{General procedure for the synthesis of $N$-(X)sulfonyl sym-(9-phenanthryl)dibenzo-16- crown-5-oxyacetamides 21-24}

Carboxylic acid 19 (1.74 g, $3.00 \mathrm{mmol})$, oxalyl chloride $(1.58 \mathrm{~mL}, 18 \mathrm{mmol})$, and benzene $(80$ $\mathrm{mL}$ ) were combined in a 1-necked flask. The mixture was stirred for $1.5 \mathrm{~h}$. The solvent was evaporated in vacuo and an infrared spectrum of the residue was taken. Disappearance of the peak at $1726 \mathrm{~cm}^{-1}$ and appearance of the peak at $\sim 1810 \mathrm{~cm}^{-1}$ verified formation of the acid chloride 20. The sulfonamide salt was prepared by adding $\mathrm{NaH}(0.72 \mathrm{~g}, 30 \mathrm{mmol})$ and THF (30 $\mathrm{mL})$ to a 3-necked flask under nitrogen. The appropriate sulfonamide $(3.6 \mathrm{mmol})$ in THF $(30 \mathrm{~mL})$ was added to the flask over a 10-min period. (Benzenesulfonamide was dried with a benzene azotrope before use.) The mixture was stirred for $1.5 \mathrm{~h}$ and then a solution of the acid chloride 20 in THF $(60 \mathrm{~mL})$ was added dropwise. The mixture was stirred overnight. After cooling to $0{ }^{\circ} \mathrm{C}$, $\mathrm{H}_{2} \mathrm{O}(20 \mathrm{~mL})$ was added to quench the reaction and stirring was continued for $30 \mathrm{~min}$. THF was evaporated in vacuo and the resultant solid was filtered. The filtrate was extracted with $\mathrm{CHCl}_{3}$ $(2 \times 75 \mathrm{~mL})$. After separation, the filtered solid was dissolved in combined $\mathrm{CHCl}_{3}$ extracts and the resulting solution was washed with $10 \%$ aq $\mathrm{K}_{2} \mathrm{CO}_{3}(2 \times 75 \mathrm{~mL})$, dried over $\mathrm{MgSO}_{4}$, and evaporated in vacuo. After purification by chromatography on silica gel or recrystallization, the 
product was dissolved in $\mathrm{CH}_{2} \mathrm{Cl}_{2}$. The solution was shaken with $6 \mathrm{~N} \mathrm{HCl}$. The organic layer was dried over $\mathrm{MgSO}_{4}$ and evaporated in vacuo to give the solid product.

$\mathrm{N}$-Methanesulfonyl sym-(9-phenanthryl)dibenzo-16-crown-5-oxyacetamide (21). Chromatography on silica gel with $\mathrm{CH}_{2} \mathrm{Cl}_{2}-\mathrm{MeOH}(19: 1)$ as eluent gave $1.50 \mathrm{~g}$ (94\%) of white solid with mp 103-104 ${ }^{\circ} \mathrm{C} . v_{\max }(\mathrm{film}) / \mathrm{cm}^{-1} 3344(\mathrm{~N}-\mathrm{H}), 1722(\mathrm{C}=\mathrm{O}), 1256,1124,1047$ (C-O), 1349, 1145 $\left(\mathrm{SO}_{2}\right) . \delta_{\mathrm{H}} 3.10(\mathrm{~s}, 3 \mathrm{H}), 3.98-3.94(\mathrm{~m}, 2 \mathrm{H}), 4.13-4.09(\mathrm{~m}, 2 \mathrm{H}), 4.27-4.18(\mathrm{~m}, 4 \mathrm{H}), 4.77(\mathrm{~s}, 2 \mathrm{H})$, $5.00(\mathrm{~d}, J 11,2 \mathrm{H}), 5.03(\mathrm{~d}, J 11,2 \mathrm{H}), 6.88-6.81(\mathrm{~m}, 6 \mathrm{H}), 6.98-6.94(\mathrm{~m}, 2 \mathrm{H}), 7.74-7.62(\mathrm{~m}, 4 \mathrm{H})$, $7.95(\mathrm{dd}, J 8,1,1 \mathrm{H}), 8.17(\mathrm{~s}, 1 \mathrm{H}), 8.71(\mathrm{~d}, J 8,1 \mathrm{H}), 8.81(\mathrm{~d}, J 8,2 \mathrm{H}), 9.58(\mathrm{~s}, 1 \mathrm{H}) . \delta_{\mathrm{C}} 41.1,65.9$, 67.2, 69.3, 72.2, 84.6, 112.9, 117.8, 121.1, 122.5, 123.3, 123.7, 126.4, 127.0, 127.7, 129.2, 129.3, 130.1, 130.3, 130.7, 130.8, 131.7, 147.5, 150.2, 170.7. Found: C, 63.41; H, 5.12; N, 2.04\%. $\mathrm{C}_{36} \mathrm{H}_{35} \mathrm{NO}_{9} \mathrm{~S} \bullet 0.4 \mathrm{CH}_{2} \mathrm{Cl}_{2}$ requires $\mathrm{C}, 63.17 ; \mathrm{H}, 5.22 ; \mathrm{N}, 2.02 \%$.

$\mathrm{N}$-Benzenesulfonyl sym-(9-phenanthryl)dibenzo-16-crown-5-oxyacetamide (22). Chromatography on silica gel with $\mathrm{CH}_{2} \mathrm{Cl}_{2}-\mathrm{MeOH}(19: 1)$ as eluent gave $1.77 \mathrm{~g}(81 \%)$ of white solid with mp 113-114 ${ }^{\circ} \mathrm{C} . v_{\max }\left(\right.$ film) $/ \mathrm{cm}^{-1} 3310(\mathrm{~N}-\mathrm{H}), 1723(\mathrm{C}=\mathrm{O}), 1256,1125,1048$ (C-O), 1344, 1138 $\left(\mathrm{SO}_{2}\right) . \delta_{\mathrm{H}} 3.88-3.74(\mathrm{~m}, 2 \mathrm{H}), 4.07-3.98(\mathrm{~m}, 4 \mathrm{H}), 4.20-4.16(\mathrm{~m}, 2 \mathrm{H}), 4.69(\mathrm{~s}, 2 \mathrm{H}), 4.94(\mathrm{~d}, J 11$, 2H), $4.97(\mathrm{~d}, J 11,2 \mathrm{H}), 6.97-6.76(\mathrm{~m}, 8 \mathrm{H}), 7.33-7.30(\mathrm{~m}, 2 \mathrm{H}), 7.52-7.49(\mathrm{~m}, 1 \mathrm{H}), 7.60-7.57(\mathrm{~m}$, $1 \mathrm{H}), 7.68-7.64(\mathrm{~m}, 2 \mathrm{H}), 7.74-7.70(\mathrm{~m}, 1 \mathrm{H}), 7.85(\mathrm{dd}, J 8,1,2 \mathrm{H}), 7.95(\mathrm{dd}, J 8,1,1 \mathrm{H}), 8.14(\mathrm{~s}$, $1 \mathrm{H}), 8.70(\mathrm{~d}, J 8,1 \mathrm{H}), 8.74(\mathrm{~d}, J 8,1 \mathrm{H}), 8.80(\mathrm{~d}, J 8,1 \mathrm{H}), 9.72(\mathrm{~s}, 1 \mathrm{H}) . \delta_{\mathrm{C}} 65.7,67.1,69.4,71.6$, $84.2,112.6,117.6,121.0,122.5,123.2,123.6,126.3,126.5,126.9,127.0,127.7,128.3,128.6$, $128.9,129.2,130.0,130.6,130.7,130.8,131.7,133.4,138.8,147.4,150.2,169.5$. Found: C, $68.04 ; \mathrm{H}, 5.08 ; \mathrm{N}, 1.97 \% . \mathrm{C}_{41} \mathrm{H}_{37} \mathrm{NO}_{9} \mathrm{~S}$ requires $\mathrm{C}, 68.41 ; \mathrm{H}, 5.18 ; \mathrm{N}, 1.94 \%$.

$\boldsymbol{N}$-(4-Nitrobenzene)sulfonyl sym-(9-phenanthryl)dibenzo-16-crown-5-oxyacetamide (23). Chromatography on silica gel with $\mathrm{CH}_{2} \mathrm{Cl}_{2}-\mathrm{MeOH}$ (19:1) as eluent gave $1.79 \mathrm{~g}$ (78\%) of yellow solid with mp $127-128{ }^{\circ} \mathrm{C}$. $v_{\max }($ film $) / \mathrm{cm}^{-1} 3329(\mathrm{~N}-\mathrm{H}), 1728(\mathrm{C}=\mathrm{O}), 1532,1312\left(\mathrm{NO}_{2}\right), 1256$, 1124, $1052(\mathrm{C}-\mathrm{O}), 1350,1160\left(\mathrm{SO}_{2}\right) . \delta_{\mathrm{H}} 3.91-3.89(\mathrm{~m}, 2 \mathrm{H}), 4.09-4.01(\mathrm{~m}, 4 \mathrm{H}), 4.20-4.16(\mathrm{~m}$, $2 \mathrm{H}), 4.73(\mathrm{~s}, 2 \mathrm{H}), 4.91(\mathrm{~d}, J 11,2 \mathrm{H}), 4.95(\mathrm{~d}, J 11,2 \mathrm{H}), 6.82-6.75(\mathrm{~m}, 6 \mathrm{H}), 6.99-6.96(\mathrm{~m}, 2 \mathrm{H})$, 7.63-7.59 (m, 1H), 7.70-7.64 (m, 2H), 7.75-7.72 (m, 1H), 7.97-7.93 (m, 3H), 8.07-8.01 (m, 3H), 8.75-8.70 (m, 2H), $8.81(\mathrm{~d}, J 8,1 \mathrm{H}), 9.85(\mathrm{~s}, 1 \mathrm{H}) . \delta_{\mathrm{C}} 65.7,67.1,69.2,71.4,84.4,112.6,117.7$, $121.1,122.5,123.5,123.6,123.7,124.0,126.4,126.5,126.8,127.1,127.8,128.7,129.2,129.6$, $129.8,130.0,130.5,130.6,130.8,131.8,144.1,147.2,150.1,150.3,169.9$. Found: C, 63.95; H, $4.92 ; \mathrm{N}, 3.64 \% . \mathrm{C}_{41} \mathrm{H}_{36} \mathrm{~N}_{2} \mathrm{O}_{11} \mathrm{~S}$ requires $\mathrm{C}, 64.39 ; \mathrm{H}, 4.74 ; \mathrm{N}, 3.66 \%$.

$\mathrm{N}$-Trifluoromethanesulfonyl sym-(9-phenanthryl)dibenzo-16-crown-5-oxyacetamide (24). Recrystallization from EtOAc-hexanes (1:1) gave $1.50 \mathrm{~g} \mathrm{(70 \% )} \mathrm{of} \mathrm{white} \mathrm{solid} \mathrm{with} \mathrm{mp} \mathrm{108-109}$ ${ }^{\circ}$ C. $v_{\max }($ film $) / \mathrm{cm}^{-1} 3304(\mathrm{~N}-\mathrm{H}), 1748(\mathrm{C}=\mathrm{O}), 1252,1135,1047(\mathrm{C}-\mathrm{O}), 1388,1204\left(\mathrm{SO}_{2}\right) . \delta_{\mathrm{H}}$ 3.94-3.91 (m, 2H), 4.07-4.03 (m, 2H), 4.26-4.18 (m, 4H), $4.95(\mathrm{~d}, J 11,2 \mathrm{H}), 5.01(\mathrm{~s}, 2 \mathrm{H}), 5.04(\mathrm{~d}$, $J 11,2 \mathrm{H}), 6.82-6.81(\mathrm{~m}, 4 \mathrm{H}), 6.88-6.87(\mathrm{~m}, 2 \mathrm{H}), 7.00-6.96(\mathrm{~m}, 2 \mathrm{H}), 7.64-7.61(\mathrm{~m}, 1 \mathrm{H}), 7.71-$ $7.66(\mathrm{~m}, 2 \mathrm{H}), 7.76-7.72(\mathrm{~m}, 1 \mathrm{H}), 7.98(\mathrm{~d}, J 8,1 \mathrm{H}), 8.17(\mathrm{~s}, 1 \mathrm{H}), 8.72(\mathrm{~d}, J 8,2 \mathrm{H}), 8.82(\mathrm{~d}, J 8$, $1 \mathrm{H}), 10.16(\mathrm{~s}, 1 \mathrm{H}) . \delta_{\mathrm{C}} 66.3,67.1,69.3,71.6,84.5,112.6,117.6,117.8,121.1,122.5,123.6,123.8$, $126.4,126.4,126.9,127.1,127.8,128.8,129.2$, 129.9, 130.7, 130.8, 131.8, 147.1, 150.2, 169.0. 
Found: C, 59.41; H, 4.28; N, 1.98\%. $\mathrm{C}_{36} \mathrm{H}_{35} \mathrm{NO}_{9} \mathrm{SF}_{3} \bullet 0.8 \mathrm{H}_{2} \mathrm{O}$ requires $\mathrm{C}, 59.55 ; \mathrm{H}, 4.66 ; \mathrm{N}$, $1.93 \%$.

\section{Extraction procedure}

An aqueous solution of the alkali metal chlorides with hydroxides for $\mathrm{pH}$ adjustment (when $\mathrm{X}=$ $\mathrm{CF}_{3}, 0.10 \mathrm{M} \mathrm{HCl}$ was utilized for $\mathrm{pH}$ adjustment) $(2.0 \mathrm{~mL}, 10.0 \mathrm{mM}$ in each alkali metal ion species) and $2.0 \mathrm{~mL}$ of $1.0 \mathrm{mM}$ ligand in chloroform in a capped, polypropylene, $15-\mathrm{mL}$ centrifuge tube was vortexed with a Glas-Col Multi-Pulse Vortexer for $10 \mathrm{~min}$ at room temperature. The tube was centrifuged for $10 \mathrm{~min}$ for phase separation with a Becton-Dickinson Clay Adams Brand ${ }^{\circledR}$ centrifuge. A $1.5-\mathrm{mL}$ portion of the organic phase was removed and added to $3.0 \mathrm{~mL}$ of $0.10 \mathrm{M} \mathrm{HCl}$ in a new, $15-\mathrm{mL}$, polypropylene centrifuge tube. The tube was vortexed for $10 \mathrm{~min}$ and centrifuged for $10 \mathrm{~min}$. The alkali metal cation concentrations in the aqueous phase from stripping were determined with a Dionex DX-120 ion chromatograph with a CS12A column. The $\mathrm{pH}$ of the aqueous phase from the initial extraction step was determined with a Fisher Accumet AR25 pH meter with a Corning 476157 combination $\mathrm{pH}$ electrode.

\section{Acknowledgements}

We thank the Division of Chemical Sciences, Geosciences and Biosciences of the Office of Basic Energy Sciences of the U. S. Department of Energy (Grant DE-FG02-90ER14416) for support of this research.

\section{References}

1. Bradshaw, J. S.; Izatt, R. M.; Bordunov, A. V.; Zhu, C. Y.; Hathaway, J. K. In Comprehensive Supramolecular Chemistry; Gokel, G. W., Ed.; Pergamon: New York, 1996, p 35.

2. Gokel, G. W.; Leevy, W. M.; Weber, M. E. Chem. Rev. 2004, 104, 2723.

3. Gokel, G. W.; Schall, O. F. In Comprehensive Supramolecular Chemistry; Gokel, G. W., Ed.; Pergamon: New York, 1996, p 97.

4. Strzelbicki, J.; Bartsch, R. A. Anal. Chem. 1981, 53, 1894.

5. Bartsch, R. A.; Ivy, S. N.; Lu, J. P.; Huber, V. J.; Talanov, V. S.; Walkowiak, W.; Park, C.; Amiri-Eliasi, B. Pure Appl. Chem. 1998, 70, 2393.

6. Walkowiak, W.; Charewicz, W. A.; Kang, S. I.; Yang, I. W.; Pugia, M. J.; Bartsch, R. A. Anal. Chem. 1990, 62, 2018.

7. Bartsch, R. A.; Lu, J. P.; Ohki, A. J. Incl. Phenom. Macro. Chem. 1998, 32, 133.

8. Bartsch, R. A.; Liu, Y.; Kang, S. I.; Son, B.; Heo, G. S.; Hipes, P. G.; Bills, L. J. J. Org. Chem. 1983, 48, 4864. 
9. Bartsch, R. A.; Dalley, N. K.; Talanov, V. S.; Purkiss, D. W.; Vogel, H. F. Tetrahedron 2005, 61, 8351.

10. Huber, V. J.; Ivy, S. N.; Lu, J. P.; Bartsch, R. A. Chem. Commun. 1997, 1499.

11. Tu, C.; Surowiec, K.; Gega, J.; Purkiss, D. W.; Bartsch, R. A. Tetrahedron 2008, 64, 1187.

12. Tu, C. Q.; Surowiec, K.; Bartsch, R. A. Tetrahedron 2007, 63, 4184.

13. Bartsch, R. A.; Bitalac, L. P.; Cowey, C. L.; Elshani, S.; Goo, M. J.; Huber, V. J.; Ivy, S. N.; Jang, Y. C.; Johnson, R. J.; Kim, J. S.; Luboch, E.; McDonough, J. A.; Pugia, M. J.; Son, B.; Zhao, Q. J. Heterocycl. Chem. 2000, 37, 1337.

14. Bartsch, R. A.; Cowey, C. L.; Elshani, S.; Goo, M. J.; Huber, V. J.; Ivy, S. N.; Johnson, R. J.; Kim, J. S.; Luboch, E.; McDonough, J. A.; Pugia, M. J.; Son, B.; Zhao, Q. J. Heterocycl. Chem. 2001, 38, 311.

15. Talanova, G. G.; Hwang, H. S.; Talanov, V. S.; Bartsch, R. A. Chem. Commun. 1998, 419.

16. Heo, G. S.; Bartsch, R. A.; Schlobohm, L. L.; Lee, J. G. J. Org. Chem. 1981, 46, 3574. 